\title{
Modulation of Thiol-Ene Coupling by the Molecular Environment of Polymer Backbones for Hydrogel Formation and Cell Encapsulation
}

\author{
Burcu Colak ${ }^{1,2 \#}$, Linke Wu ${ }^{1,2 \#}$, Edward J. Cozens ${ }^{1,2}$ and Julien E. Gautrot ${ }^{1,2 *}$ \\ ${ }^{1}$ Institute of Bioengineering and ${ }^{2}$ School of Engineering and Materials Science, Queen \\ Mary, University of London, Mile End Road, London, E1 4NS, UK. \\ * To whom correspondence should be addressed E-mail: j.gautrot@qmul.ac.uk. \\ \# These authors contribute equally to this work.
}

\begin{abstract}
Thiol-ene radical coupling is increasingly used for the biofunctionalisation of biomaterials and the formation of 3D hydrogels enabling cell encapsulation. Indeed, thiol-ene chemistry presents interesting features that are particularly attractive for platforms requiring specific reactions of peptides or proteins, in particular in situ, during cell culture or encapsulation: thiol-ene coupling occurs specifically between a thiol and a non-activated alkene (unlike Michael addition); it is relatively tolerant to the presence of oxygen; it can be triggered by light. Despite such interest, little is known about the factors impacting polymer thiol-ene chemistry in situ. Here we explore some of the molecular parameters controlling photoinitiated thiol-ene coupling (with UV and visible light irradiation), with a series of alkenefunctionalised polymer backbones. ${ }^{1} \mathrm{H}$ NMR spectroscopy is used to quantify the efficiency of couplings, whereas photo-rheology allows correlation to gelation and mechanical properties of the resulting materials. We identify the impact of weak electrolytes in regulating coupling efficiency, presumably via thiol deprotonation and regulation of local diffusion. The conformation of associated polymer chains, regulated by the $\mathrm{pH}$, is also proposed to play an important role in the modulation of both thiol-ene coupling and crosslinking efficiencies. Ultimately, suitable conditions for cell encapsulations are identified for a range of polymer backbones and their impact on cytocompatibility is investigated for cell encapsulation and tissue engineering applications. Overall our work demonstrates the importance of polymer backbone design to regulate thiol-ene coupling and in situ hydrogel formation.
\end{abstract}

\section{Keywords}

Hydrogel; Thiol-ene; Norbornene; Photo-initiation; Cell encapsulation; Rheology. 


\section{Introduction}

Thiol-ene radical coupling is now widely used for the development of biomaterials, and in particular for hydrogel design, from scaffolds for 3D cell culture and tissue engineering ${ }^{1,2}$, to controlled release platforms ${ }^{3,4}$ and for the functionalisation of biointerfaces ${ }^{5,6}$ and biosensors $^{7,8}$. The simplicity with which thiol residues can be introduced in peptide sequences and on polymer backbones has enabled the integration of a wide range of polymer backbones including non-degradable poly(ethylene glycol)-based star polymers ${ }^{9,10}$ and glycosaminoglycans such as hyaluronic acid ${ }^{11}$ and chondroitin sulfate ${ }^{12}$, to degradable backbones such as gelatin ${ }^{13}$. This flexibility enables the design of multi-functional and responsive matrices, for example allowing the control of mechanical properties, matrix density, charge, cell adhesion or cell-mediated degradability ${ }^{14-16}$. In addition, the cytocompatibility of this coupling, even with UV initiated systems ${ }^{17}$, enables the temporal control of mechanical properties ${ }^{15}$, cell adhesion ${ }^{18}$ and patterning of biomaterials and hydrogels ${ }^{14,19}$.

Although parameters controlling the kinetics and reactivity of alkenes with thiol molecules have been explored extensively, in particular in the context of organic synthesis and hydrophobic resin curing ${ }^{20-23}$, the impact of environmental molecular factors on thiol-ene radical chemistry in aqueous media should be studied more extensively. Activated alkenes such as acrylates and methacrylates support radical thiol-ene mechanisms, however these can also result in competing chain growth polymerisations. In contrast, strained norbornene residues are particularly active with respect to thiol-ene propagation and chain transfer steps $^{21,23}$, followed by vinyl ethers and vinyl silazanes. The impact of thiol chemistry has received comparatively less attention, however it has emerged as an important factor regulating thiol-ene radical efficiency ${ }^{24}$, primarily through the modulation of the pKa of corresponding thiolates and transfer of radical to moieties, for example present in natural 
amino acids. Therefore, such considerations may have a direct impact on the design of bioactive peptide sequences for coupling to biomaterials via thiol-ene coupling or Michael additions. In addition, although a restricted number of photoinitiators have been proposed for UV-light activation (i.e. mainly Irgacure 2959 and lithium acylphosphinate), initiators suitable for visible light activation have also been proposed ${ }^{25-28}$. Although these initiators, including Eosin $\mathrm{Y}$, have the advantage of avoiding the use of UV light and to be very water soluble and cytocompatible, their efficiency for the promotion of radical thiol-ene coupling has not been extensively examined. However, their chemical structure predicts a very strong impact of the molecular environment and $\mathrm{pH}$ on their photo-active properties.

In turn, some of the parameters regulating the mechanical properties of radical thiol-ene based hydrogels have been explored. As for other hydrogel design, the concentration of polymer and monomer solutions used during crosslinking has a criticial impact on the macroscopic mechanical properties of thiol-ene hydrogels, with moduli ranging from the 0.1$100 \mathrm{kPa}^{1,29-31}$. In addition, the degree of functionalisation (either of thiols or alkene residues) $)^{32}$ and the molecular weight of the polymer backbones also regulate mechanical properties of these hydrogels, as altering the molar mass between crosslinks and regulating local crosslinking densities. In this respect, thiol-ene based networks display better control of local heterogeneity than their counterparts formed via chain growth polymerisation of acrylates and acrylamides (as in polyacrylamide and poly(oligoethylene glycol acrylate)) ${ }^{33}$, at least prior to swelling, although loop defects are still expected to contribute to delay gelation and alter mechanical behaviours. Finally, the ratio of thiol and alkene residues has been shown to play an essential role in the control of thiol-ene hydrogel mechanics and gelation kinetics ${ }^{14,27,34,35}$. Typically, stoechiometric alkene:thiol ratios typically lead to fastest gelation and highest shear moduli. However, it is often necessary to retain a significant fraction of free alkenes (or thiols, depending on the system) for functionalisation with mono-functional bioactive molecules such as cell adhesive peptides or growth factors. 
Therefore, the study of off-stoehiometric hydrogels has important practical applications in the field of tissue engineering.

Comparatively, the impact of macromolecular structure on thiol-ene radical coupling reactivity and how, in turn, this regulates crosslinking and, ultimately, mechanical properties should be further studied. For example, the presence of acidic and basic residues that may alter the charge density along polymer backbones, the local concentration of thiols, the local molecular diffusion and chain conformation, has received little attention with respect to its impact on thiol-ene coupling efficiency and mechanical properties. In this study, a range of alkene-functionalised polymer backbones has been synthesised, displaying polycationic, polyanionic and neutral hydrophilic structures. The impact of such architectures, combined to the $\mathrm{pH}$ of the medium, on thiol-ene coupling efficiency is quantified by NMR. In the case of norbornene derivatives, comparisons are made between UV- and visible-light initiated systems. In turn, the impact of this molecular environment on hydrogel mechanics is explored by photo-rheology (Figure 1) and compared to other factors regulating mechanical properties, such as polymer concentration. Finally, we investigate the use of these hydrogels for the encapsulation of endothelial cells and fibroblasts.

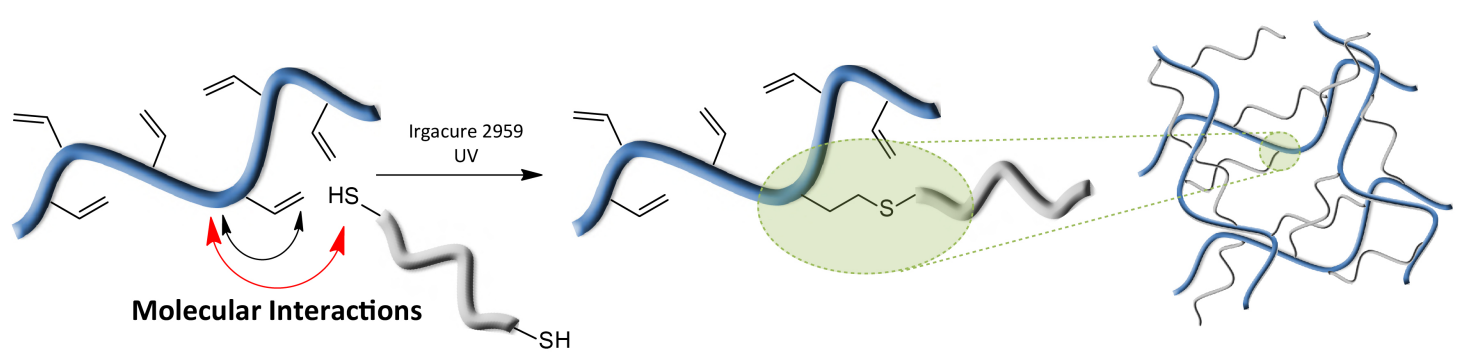

Figure 1. Schematic representation of thiol-ene radical reaction and hydrogel formation based alkene-functionalised polymer backbones and dithiol terminated crosslinkers. The black and red arrows indicate local interactions between the alkene and thiol residues with the molecular structure of the polymer backbone, affecting the efficiency of the thiol-ene coupling. 


\section{Experimental section}

Materials. Methanol (99.9\%), ethanol (99.5\%), eosin Y (99\%), Triethanolamine (TEOA, 99\%, hydrochloric acid), 1-ethyl-3-(3-dimethylaminopropyl)carbodiimide hydrochloride (EDC), N-hydroxysuccinimide (NHS), 3-(trimethoxysilyl)propyl methacrylate (98\%), $\mathrm{N}$ acetyl L-cysteine (99\%), allylamine (98\%), PBS tablets, Dulbecco's PBS, 2-hydroxy-4'-(2hydroxyethoxy)-2-methylpropiophenone (IRG2959, 98\%), poly(ethylene glycol) dithiol (PEGDT, $M_{n}$ 1000), triethylamine (99\%), 4-pentenoyl chloride (98\%), 5-bromo-1-pentene (95\%), 2-(dimethylamino)ethyl methacrylate (containing 700-1000 ppm monomethyl ether hydroquinone as inhibitor, 98\%), ethyl a-bromoisobutyrate (98\%), ethanol (99.8\%), 2,2'bipyridine (>99\%), copper (I) chloride (>99.995\% trace metals basis), poly(methyl vinyl ether alt-maleic anhydride) $\left(M_{\mathrm{w}} \sim 216 \mathrm{~kg} / \mathrm{mol}\right.$ average $\left.M_{\mathrm{n}} \sim 80 \mathrm{~kg} / \mathrm{mol}\right)$, 2-chloroethylamine hydrochloride (99\%), 2-ethyl-2-oxzoline $(99 \%)$, methyl p-toluenesulfonate $(97 \%)$, sodium carboxymethyl cellulose ( $\mathrm{M}_{\mathrm{w}} 90$ and $250 \mathrm{~kg} / \mathrm{mol}$, degree of substitution 0.7$)$, allyl bromide (97\%), anhydrous dimethylsulfoxide (>99.9), sodium hydroxide pellets, poly(acrylic acid) $\left(\mathrm{M}_{\vee}\right.$ $\sim 450 \mathrm{~kg} / \mathrm{mol})$, deuterium oxide $(99.9 \%$ atom $\% \mathrm{D}$ ), deuterium chloride solution (37 $\mathrm{wt} \%$ in deuterium oxide, $99 \%$ atom $\%$ D), sodium deuteroxide ( $40 \%$ in deuterium oxide 99 atom\% D), hydrochloric acid (37\%), anhydrous magnesium sulphate (99.5\%), sodium bicarbonate (99.7\%), sodium chloride (99.5\%), sodium hydroxide (97\%), dichloromethane $(99.5 \%)$, anhydrous acetonitrile (99.8\%), anhydrous dichloromethane (99.8\%), anhydrous dimethylformamide (99.8\%), methanol (HPLC 99.9\%), tetrahydrofuran (99.9\%), diethyl ether (99\%), , acetonitrile (HPLC 99.9\%), heptane (HPLC 99\%), dimethylformamide (pharmaceutical secondary standard) and silica gel were obtained from Sigma Aldrich. Chloroform (AnalaR $0.6 \%$ of ethanol) and acetone (GPR) was purchased from VWR. Potassium permanganate (98\%) was purchased from Alfa Aesar. Chloroform-D (99.8\%) 
was purchased from Cambridge Isotope Laboratories Inc. Sodium hyaluronic acid (HA, 200 kDa) was purchased from Lifecore Itd. 5-norbornene-2-ethylamine was ordered from Tokyo Chemical Industry Co. Ltd.

Instrumentation. ${ }^{1} \mathrm{H}$ NMR spectroscopy was carried out using a Bruker AV 400 and AVIII 400. Details of assignment of peaks can be found in the Supplementary Information. ATRFTIR were produced using a Bruker Tensor 27 spectrometer equipped with a MCT detector. Results were acquired at a resolution of $16 \mathrm{~cm}^{-1}$ and a total of 128 scans per run in the region of $600-4000 \mathrm{~cm}^{-1}$. A Leica DMI4000B epifluorescent microscope fitted with a HCX PL FLUOTAR 10x/0.3 PJ1 objective and a Leica DFC300 FX CCD camera was used to image cells in 3D hydrogels. Rheological measurements were performed using a DHR-3 rheometer from TA Instruments fitted with a UV accessory and a $20 \mathrm{~mm}$ upper parallel plate. The UV curable gels were sandwiched between two coverslips glued to the plates of the rheometer at a fixed gap of $250 \mu \mathrm{m}$. Coverslips were functionalised with a monolayer of methacrylate as previously reported ${ }^{36}$ : glass coverslips $(20 \mathrm{~mm})$ were plasma oxidised for 10 min and incubated in a solution of anhydrous toluene $(30 \mathrm{~mL})$ with 3-(trimethoxysilyl)propyl methacrylate $(30 \mu L)$ and triethylamine $(50 \mu L)$ for $24 \mathrm{~h}$. The slides were washed with deionised water followed by ethanol and dried under a stream of nitrogen. The glass slides were glued to the quartz bottom plate and top geometry before rheology measurements. Oscillations were set to controlled strain mode at $1 \%$ strain. For in situ monitoring of the progression of gelation, a time sweep was performed: $30 \mathrm{~s}$ of equilibrium without UV exposure, UV irradiation for 2 min and the UV light was turned off for the remaining part of the experiment. Frequency sweep and amplitude sweep measurements were carried out after UV curing. A Thorlabs fiber light source $(400-1300 \mathrm{~nm})$ was used for visible light photo rheology and the light intensity was adjusted to $50 \mathrm{~mW} / \mathrm{cm}^{2}$. 
TGA measurements were performed using a TGA Q500 from TA instruments, $25-1000^{\circ} \mathrm{C}$ ramp, $3^{\circ} \mathrm{C} / \mathrm{min}$. TGA traces were analysed to calculate the percentage of water and swelling of the gels. The percentage of water in gels (W\%) was calculated from the percentage of polymer in the gel $(P)$ obtained from the TGA traces: $W \%=100-P$ (equation 1). The degree of swelling of gels (Ws) was calculated from the percentage of water in the gel before $(W i)$ and after (Wf) swelling in PBS (or water, depending on the conditions): Ws (\%)= $(W f-W i) / W i$ (equation 2). GPC analysis was performed using an Agilent 1260 Infinity system equipped with a refractive index and variable wavelength detector, 2 PLgel $5 \mu \mathrm{m}$ mixed-C column $(300 \times 7.5 \mathrm{~mm})$, a PLgel $5 \mathrm{~mm}$ guard column $(50 \times 7.5 \mathrm{~mm})$ operated in DMF with $\mathrm{NH}_{4} \mathrm{BF}_{4}(5 \mathrm{mM})$. The instrument was calibrated with poly(methyl methacrylate) standards ( 5.5 to $46.9 \mathrm{~kg} / \mathrm{mol}$ ). All samples were filtered through $0.2 \mu \mathrm{m}$ nylon 66 before analysis.

Statistical analysis. All data were analysed by Tukey's test and significance was determined by ${ }^{*} p<0.05,{ }^{* *} p<0.01:{ }^{* * *} p<0.001$. A full summary of statistical analysis is shown in Tables S1-4.

Synthesis of polymers ${ }^{37}$. Synthesis and funtionalisation of alkene functional poly(dimethylamino ethyl methacrylate) (P1). The synthesis of PDMAEMA was modified from another protocol (Scheme S1) $)^{38}$. A solution of ethanol:deionised water (1:4) was prepared and degassed for $30 \mathrm{~min}$. 2-(dimethylamino) ethyl methacrylate $(0.0954 \mathrm{~mol})$ was weighed into a flask containing ethyl a-bromoisobutyrate $(0.00037 \mathrm{~mol})$, dissolved in ethanol-water 1:4 (7.5 mL) and degassed for $30 \mathrm{~min}$. Into a second flask, 2,2'-bipyridine (0. $19 \mathrm{mmol})$ was weighed dissolved in ethanol-water 4:1 $(7.5 \mathrm{~mL})$ and degassed for $30 \mathrm{~min}$. To the $2,2^{\prime}$-bipyridine solution was added copper (I) chloride $(0.19 \mathrm{mmol})$, the brown solution was sonicated for 10 minutes. The catalyst solution was transferred to the monomer solution and the reaction was stirred under inert atmosphere for $5 \mathrm{~h}$ at $50^{\circ} \mathrm{C}$. The ethanol was 
evaporated prior to freeze-drying of the remaining solution. The obtained solid was dissolved in tetrahydrofuran and added to silica gel $(20 \mathrm{~g})$, agitated for $1 \mathrm{~h}$, filtered and concentrated using a rotary evaporator, then precipitated in heptane, filtered and dried under reduced pressure. PDMAEMA characterisation: GPC, $M_{\mathrm{n}} 67.9 \mathrm{~kg} / \mathrm{mol}, \Xi_{\mathrm{M}}$ 1.6. ${ }^{1} \mathrm{H} \mathrm{NMR},(400 \mathrm{MHz}$; $\left.\mathrm{D}_{2} \mathrm{O}\right) \delta$ 0.75-1.2 (3H, m), 1.7-2.0 (2H, m), $2.3(6 \mathrm{H}, \mathrm{s})$, 2.6-2.8 $(2 \mathrm{H}, \mathrm{m})$ and $4.1(2 \mathrm{H}, \mathrm{m})$ (Figure S1a). FTIR, v/cm-1 2900 (w, C-H), 1720 (s, C=O), 1261 (m, C-N) and 1100 (s, C-O).

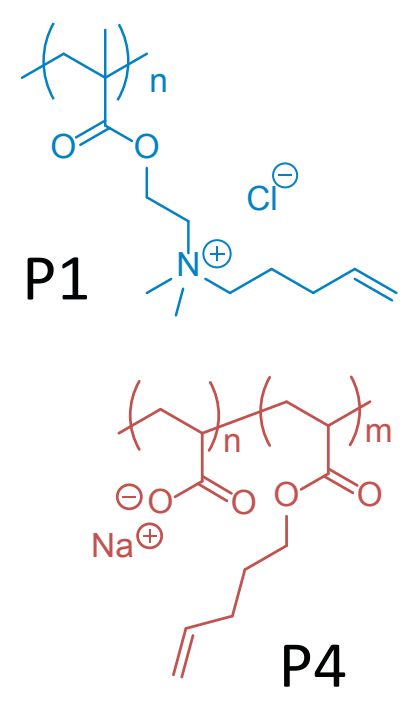

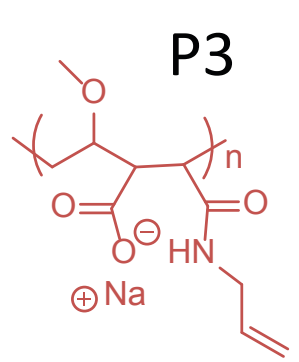

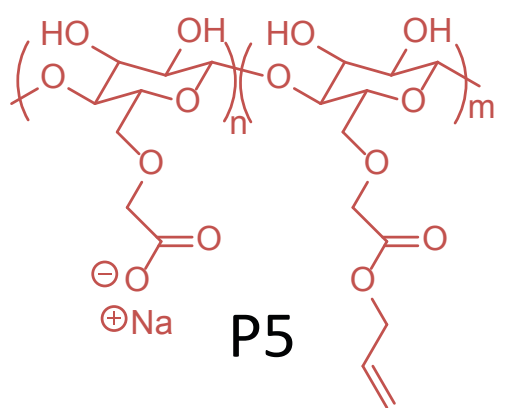

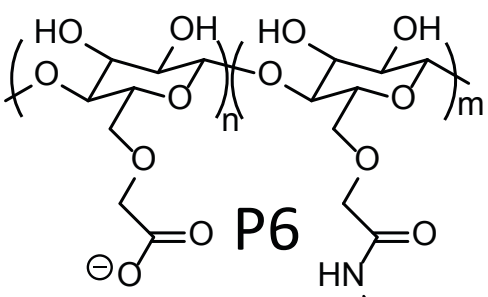

$\oplus \mathrm{Na}$
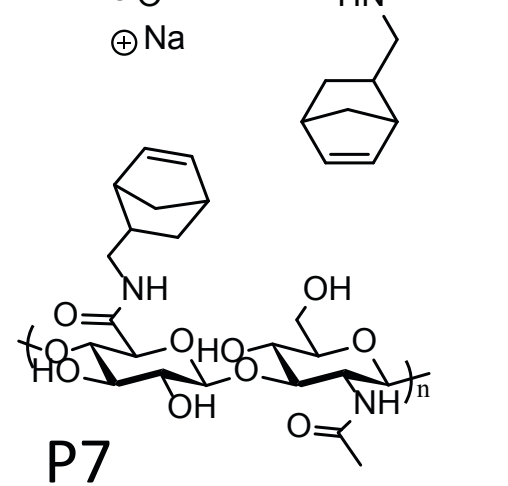

Scheme 1. Chemical structure of the different alkene-functionalised polymers studied.

PDMAEMA (1 eq., $1 \mathrm{~g}, 0.0064 \mathrm{~mol}$ ) was then dissolved in dimethylformamide $(10 \mathrm{~mL}$ ), and 5-bromo-1-pentene (2.5 eq., $0.015 \mathrm{~mol}$ ) was added before the reaction mixture was stirred overnight at $70^{\circ} \mathrm{C}$. The resulting polymer was precipitated in diethyl ether and the remaining solid was dissolved in methanol and precipitated in diethyl ether. The recovered polymer was precipitated from methanol twice more. The polymer (P1) was recovered and dried under reduced pressure. ${ }^{1} \mathrm{H}$ NMR, $\left(400 \mathrm{MHz} ; \mathrm{D}_{2} \mathrm{O}\right) \delta$ 0.85-1.4 $(3 \mathrm{H}, \mathrm{m}), 1.9-2.1(2 \mathrm{H}, \mathrm{m}), 2.1-$ $2.3(4 \mathrm{H}, \mathrm{m}), 3.3(6 \mathrm{H}, \mathrm{s}), 3.4-3.5(2 \mathrm{H}, \mathrm{m}), 3.7-4.0(2 \mathrm{H}, \mathrm{m}), 4.3-4.6(2 \mathrm{H}, \mathrm{m})$ 5.0-5.2 $(2 \mathrm{H}, \mathrm{m})$ and 5.8-6.0 (1H, m) (Figure S1b). FTIR, v/cm ${ }^{-1} \sim 2900(\mathrm{w}, \mathrm{C}-\mathrm{H}), 1727(\mathrm{~s}, \mathrm{C}=\mathrm{O}), 1643(\mathrm{w}$, 
$\mathrm{C}=\mathrm{C}), 1243(\mathrm{~m}, \mathrm{C}-\mathrm{N})$ and 1137 (s, C-O) (Figure S2). GPC $M_{\mathrm{n}} 67.9 \mathrm{~kg} / \mathrm{mol}, \emptyset_{\mathrm{M}} 1.60 \mathrm{measured}$ in DMF with $\mathrm{NH}_{4} \mathrm{BF}_{4}(5 \mathrm{mM})$. The alkene functionalisation level was calculated as $100 \%$.

Synthesis of 2-butenyl-2-oxazoline. The monomer 2-butenyl-2-oxazoline was synthesised following an adapted protocol reported by Gress et al (Scheme S2). ${ }^{39}$ 2-chloroethylamine hydrochloride (1.2 eq., $0.092 \mathrm{~mol}$ ) was transfered to a round bottom flask and purged with inert gas for 30 minutes. Anhydrous dimethylformamide $(80 \mathrm{~mL})$ was subsequently added, under inert atmosphere. The flask was placed into an ice bath under inert gas atmosphere and triethylamine (2.5 eq., $0.194 \mathrm{~mol})$ was added, followed by dichloromethane $(75 \mathrm{~mL})$ and pentenoyl chloride (1 eq., $0.077 \mathrm{~mol}$ ). The reaction was stirred in a water bath for $24 \mathrm{~h}$ under inert atmosphere. A brown solution and cream precipitate formed. The flask content was added into a separation funnel with dichloromethane $(200 \mathrm{~mL})$. With the addition of dichloromethane, the precipitate dissolved. The organic solution was extracted from hydrochloric acid (1M, $500 \mathrm{~mL}$ four times), saturated sodium carbonate (500 $\mathrm{mL}$ twice), then from brine (500 mL, four times). The organic layers were recovered and dried over magnesium sulphate. The organic layer was evaporated to yield a brown oil. ${ }^{1} \mathrm{H}$ NMR, (400 $\left.\mathrm{MHz} ; \mathrm{CDCl}_{3}\right)$ 2.2-2.35 (4H, m), 3.55 $(4 \mathrm{H}, \mathrm{m})$, 4.9-5.0 $(2 \mathrm{H}, \mathrm{m})$ and 5.7-5.9 $(1 \mathrm{H}, \mathrm{m})$. Crushed potassium hydroxide (1eq., $0.08 \mathrm{~mol}$ ) was added to an oven-dried round bottom flask and the system was purged with inert gas for $30 \mathrm{~min}$. Dry methanol (40 mL) was added, followed by $\mathrm{N}$-(2-chloroethyl)-4-pentenamide (1eq.). The reaction was heated to $70^{\circ} \mathrm{C}$ for $24 \mathrm{~h}$. The potassium chloride salt that precipitated was filtered and the remaining solution was evaporated. The content was distilled over calcium hydride to yield a clear oil. ${ }^{1} \mathrm{H}$ NMR, $(400$ $\left.\mathrm{MHz} ; \mathrm{CDCl}_{3}\right) 2.4(4 \mathrm{H}, \mathrm{m}), 3.8(2 \mathrm{H}, \mathrm{t}), 4.3(2 \mathrm{H}, \mathrm{t}), 5.0-5.1(2 \mathrm{H}, \mathrm{m})$ and 5.8-5.9 $(1 \mathrm{H}, \mathrm{m})$. FTIR, v/cm ${ }^{-1} 2900$ (w, C-H), 1675 (s, C=O), 1174 (w, C-N). 
Synthesis of poly(2-butenyl-2-oxazoline)-co-(2-ethyl-2-oxazoline) (P2).

2-Ethyl-2-oxazoline (distilled over calcium hydride, 80 eq., 0.08 ), 2-butenyl-2-oxazoline (20 eq.) and anhydrous acetonitrile $(20 \mathrm{~mL})$ were added into a microwave flask containing a magnetic stirrer. Methyl $p$-toluenesulfonate (1 eq.) was then added against a flow of nitrogen. The reaction vessel was heated using a microwave reactor, $140{ }^{\circ} \mathrm{C}$ for 30 minutes. ${ }^{40}$ The reaction was terminated by addition of a drop of water and precipitated in cold diethyl ether three times. The remaining polymer (P2) was recovered and dried under reduced pressure. ${ }^{1} \mathrm{H}$ NMR, $\left(400 \mathrm{MHz} ; \mathrm{CDCl}_{3}\right) 1.1(2 \mathrm{H}, \mathrm{m}), 2.1-2.5(8 \mathrm{H}, \mathrm{m}), 3.4(2 \mathrm{H}, \mathrm{m}), 5.0$ $(2 \mathrm{H}, \mathrm{m})$ and $5.8(1 \mathrm{H}, \mathrm{m})$ (Figure S3). FTIR, v/cm ${ }^{-1} \sim 3400(\mathrm{br}, \mathrm{O}-\mathrm{H}), \sim 2900(\mathrm{w}, \mathrm{C}-\mathrm{H}), 1633$ (s, C=O), 1180 (w, C-N) (Figure S4). The copolymer composition was calculated as 15\% of butenyl side chains. GPC $M_{\mathrm{n}} 6.3 \mathrm{~kg} / \mathrm{mol}, \bigoplus_{\mathrm{M}} 1.62$ measured in $\mathrm{DMF}$ with $\mathrm{NH}_{4} \mathrm{BF}_{4}(5 \mathrm{mM})$.

Synthesis of allylamine functionalised poly(methyl vinyl ether alt-maleic anhydride) (P3). Allylamine (1 eq., $0.08 \mathrm{~mol})$ was dissolved in acetonitrile $(250 \mathrm{~mL})$. Poly (methyl vinyl ether alt-maleic anhydride) (1eq.) was dissolved in acetonitrile $(200 \mathrm{~mL})$ in a second flask. The poly(methyl vinyl ether alt-maleic anhydride) solution was slowly added to the amine solution with vigorous stirring. On addition of poly(methyl vinyl ether alt-maleic anhydride) to the allylamine, a white precipitate formed. The mixture was stirred at $70{ }^{\circ} \mathrm{C}$ for $24 \mathrm{~h}$ and room temperature for $48 \mathrm{~h}$. The acetonitrile was evaporated and dissolved in distilled water. The polymer (P3) was precipitated in acidic water and recovered by freeze drying (Scheme S3). ${ }^{1} \mathrm{H}$ NMR, $\left(400 \mathrm{MHz} ; \mathrm{D}_{2} \mathrm{O}\right)$ 1.3-2.2 (2H, m), 2.5-3.0 (2H, m), 3.1-3.5 (3H, m), 3.6-3.8 (2H, m), 4.0-4.2 (1H, m), 5.0-5.3 (2H) and 5.6-5.9 (1H, m) (Figure S5). FTIR, v/cm ${ }^{-1} \sim 3400(\mathrm{br}, \mathrm{O}-\mathrm{H})$, 2900 (w, C-H), $1556(\mathrm{~s}, \mathrm{C}=\mathrm{O}), 1388(\mathrm{w}, \mathrm{C}-\mathrm{N})$ and $1072(\mathrm{w}, \mathrm{C}-\mathrm{O})$ (Figure S6). The functionalisation ratio was found to be quantitative (100\%).

Synthesis of poly(acrylic acid-co-pentenyl acrylate) (P4). Poly (acrylic acid) (1 eq., 5 g, 0.069 mol) was dissolved in a sodium hydroxide solution (1 mol/L, $52.5 \mathrm{~mL})$. 5-bromo-1-pentene 
(0.25 eq., $0.0174 \mathrm{~mol}$ ) was dissolved in dimethylformamide $(10 \mathrm{~mL})$ and the resulting solution was then transferred to the poly (acrylic acid) solution. The mixture was heated to $70{ }^{\circ} \mathrm{C}$ overnight. The cooled reaction mixture was precipitated in acetone: diethyl ether (3:1) redissolved in deionised water and precipitated in acetone again. The polymer P4 was dried under reduced pressure (Scheme S4). ${ }^{1} \mathrm{H}$ NMR, $\left(400 \mathrm{MHz} ; \mathrm{D}_{2} \mathrm{O}\right) \delta$ 1.5-1.7 $(6 \mathrm{H}, \mathrm{m}), 2.1(1 \mathrm{H}$, m), $4.0(2 \mathrm{H}, \mathrm{m}), 5.0(2 \mathrm{H}, \mathrm{m})$, and $5.86(1 \mathrm{H}, \mathrm{m})$ (Figure S7). FTIR, v/cm ${ }^{-1} \sim 3400(\mathrm{w} . \mathrm{O}-\mathrm{H})$, 2900 (w, C-H), $1679(\mathrm{~m}, \mathrm{C}=\mathrm{O})$ and $1552(\mathrm{~s}, \mathrm{C}=\mathrm{O})$ (Figure S8). The functionalisation ratio was calculated as $5.2 \%$.

Synthesis of carboxymethyl cellulose allyl ester (P5). Sodium carboxymethyl cellulose (1 eq., $0.0048 \mathrm{~mol})$ was dissolved in distilled water $(50 \mathrm{~mL})$ and a solution of allyl bromide $(0.76$ eq., $0.00366 \mathrm{~mol})$ in dimethylsulfoxide $(50 \mathrm{~mL})$ was added to this mixture, and stirred overnight at $70^{\circ} \mathrm{C}$. The resulting product $\mathbf{P 5}$ was purified by two successive precipitation in acetone and dried under reduced pressure (Scheme S5). ${ }^{1} \mathrm{H} \mathrm{NMR},\left(400 \mathrm{MHz} ; \mathrm{D}_{2} \mathrm{O}\right) \delta 3.2-$ $4.6(18 \mathrm{H}, \mathrm{m}) 5.45(2 \mathrm{H}, \mathrm{m})$ and $6.0(1 \mathrm{H}, \mathrm{m})$ (Figure S9). FTIR, v/cm ${ }^{-1} \sim 3300(\mathrm{~m}, \mathrm{O}-\mathrm{H}), \sim 2900$ (w, C-H), $1589(\mathrm{~s}, \mathrm{C}=\mathrm{O})$ and 1008 (s, C-O) (Figure S10). The functionalisation ratio was calculated as $13.4 \%$.

Synthesis of functionalised norbornene-carboxymethyl cellulose (P6) and norbornenefunctionalised hyaluronic acid (P7). Functionalised CMC-NB (P6) was synthesised following a protocol adapted from the literature ${ }^{41}$. In brief, $0.25 \mathrm{~g}(1.2 \mathrm{mmol}$ of repeat units $)$ of sodium CMC (CMC 90 kDa was used for NMR experiment whereas CMC 250 kDa was used for rheology and gelation studies) were dissolved in $25 \mathrm{~mL}$ deionized water. $0.148 \mathrm{~g}$ (0.77 $\mathrm{mmol})$ EDC and $89 \mathrm{mg}(0.77 \mathrm{mmol}) \mathrm{NHS}$ were added to the solution, prior to $0.1 \mathrm{~mL}(0.8$ $\mathrm{mmol}$ ) of 5-norbornene-2-ethylamine. The solution became cloudy and was left to stir for 18 to $24 \mathrm{~h}$ at room temperature. The solution was added dropwise to $250 \mathrm{~mL}$ ice-cold acetone containing sodium chloride $(0.75 \mathrm{~g})$ and stirred for an hour at room temperature. Acetone 
was decanted to yield a white precipitate. The precipitate was dissolved in $22 \mathrm{~mL}$ of deionized water and dialyzed for $3 \mathrm{~d}$ prior to removing water by lyophilization, affording a white powder of purified CMC-NB P6. ${ }^{1} \mathrm{H}$ NMR $\left(400 \mathrm{MHz} ; \mathrm{D}_{2} \mathrm{O}\right) \delta 3.2-4.6(18 \mathrm{H}, \mathrm{m})$ and 5.9$6.4(2 \mathrm{H}, \mathrm{m})$. The functionalisation ratio was calculated as $22.5 \%$. HA-NB (P7) was synthesized following the same protocol. ${ }^{1} \mathrm{H}$ NMR $\left(400 \mathrm{MHz} ; \mathrm{D}_{2} \mathrm{O}\right) \delta 1.8(3 \mathrm{H}, \mathrm{m})$ 5.9-6.4 $(2 \mathrm{H}$, m). The functionalisation ratio was calculated as $19 \%$.

Quantification of thiol-ene coupling efficiency via ${ }^{1} \mathrm{H}-\mathrm{NMR}$. Thiol-ene coupling between the different polymers studied (P1-P3, $45 \mathrm{mM}$ with respect to alkenes) and $\mathrm{N}$-acetyl $\mathrm{L}$ cysteine $(45.4 \mu \mathrm{mol}, 45 \mathrm{mM})$ was quantified by ${ }^{1} \mathrm{H}$ NMR, in deuterated-PBS (1 mL; see Scheme S6 for model reaction with P2). A stock solution for Irgacure 2959 was prepared in methanol $(0.198 \mathrm{M}, 0.0444 \mathrm{~g} / \mathrm{mL}) .5 \mathrm{~mol} \%(12.5 \mu \mathrm{L}$; final concentration of $2.25 \mathrm{mM})$ of photoinitiator were added to the polymer mixture from this stock solution. The $\mathrm{pH}$ of the solutions was adjusted using the $\mathrm{NaOD}$ or $\mathrm{DCl}$. The samples were irradiated with UV (17 $\mathrm{mW} / \mathrm{cm}^{2}, 350-500 \mathrm{~nm}$ ) $300 \mathrm{~s}$ (power $5.10 \mathrm{~J} / \mathrm{cm}^{2}$ ). The UV light source (strictly speaking blue to UV light) used to initiate reactions was an Omnicure series 1500 lamp. An ILT 1400-A radiometer photometer from international light technologies was used to measure the UV light intensity. ${ }^{1} \mathrm{H}$ NMR was analysed (Figure S11 for examples for P2) and conversions were calculated via the consumption of the alkene peaks with respect to the formation of the product peaks.

To study coupling with P4, a similar protocol was used, with the following changes: $N$-acetyl L-cysteine (14 $\mu \mathrm{mol}, 14 \mathrm{mM}$ ) and alkene-functionalised polymer (P4) $(0.025 \mathrm{~g}, 14 \mu \mathrm{mol}, 14$ $\mathrm{mM}$ ) were dissolved in deuterated-PBS. To these thiol-ene solutions were added $1 \mathrm{~mol} \%$ (final concentration, $140 \mu \mathrm{M}$ ) photoinitiator from the stock solution. The $\mathrm{pH}$ values of the solutions were adjusted prior to irradiation with UV light (300 s, $\left.52 \mathrm{~mW} / \mathrm{cm}^{2} 15.6 \mathrm{~J} / \mathrm{cm}^{2}\right)$. For coupling with P5, $N$-acetyl L-cysteine $(23.6 \mu \mathrm{mol}, 23.5 \mathrm{mM})$ and the alkene-functionalised 
polymer P5 (0.05 g, $23.5 \mu \mathrm{mol}, 23.5 \mathrm{mM})$ were dissolved in deuterated-PBS (1 mL). To these thiol-ene solutions was added $4.4 \mathrm{~mol} \%$ ( $1 \mathrm{mM}$ final concentration) photoinitiator from stock solution. The $\mathrm{pH}$ values of the solutions were adjusted and irradiated with UV as above (300 s, $\left.5.10 \mathrm{~J} / \mathrm{cm}^{2}\right)$. For coupling with P6, $N$-acetyl $L$-cysteine $(34.5 \mu \mathrm{mol}, 34.5 \mathrm{mM})$ and the norbornene-functionalised P6 (0.05 g, $34.5 \mu \mathrm{mol}, 34.5 \mathrm{mM})$ were dissolved in deuterated-PBS (1 mL, 1:1 thiol:alkene ratio). To the thiol-ene solution was added $5 \mathrm{~mol} \%$ (1.725 $\mathrm{mM})$ of photoinitiator from a stock solution. The $\mathrm{pH}$ value of the solutions was adjusted and the resulting solutions were irradiated with UV as above $\left(300 \mathrm{~s}, 5.10 \mathrm{~J} / \mathrm{cm}^{2}\right)$.

Hydrogel preparation. To make hydrogels for mechanical characterisation and swelling, solutes were dissolved in PBS: polymer backbones (P1-P7), crosslinkers (PEGDT) and IRG 2959 (from a $250 \mathrm{mg} / \mathrm{mL}$ solution in in methanol). Crosslinked hydrogels (thiol:ene 0.5:1 for P1-P4 and 0.64:1 for P5) were generated see Tables 1 and 2 for details. For P5, P6 and P7 gels at different $\mathrm{pH}$, solutions at $10 \mathrm{mg} / \mathrm{mL}$ were prepared and the $\mathrm{pH}$ of the gel mixture was altered using sodium hydroxide or hydrochloric acid. The gel mixtures were transferred to the rheology geometry (quartz plate), for characterisation of shear properties, and $8 \mathrm{~mm}$ cylindrical moulds for TGA and FTIR characteristion. Curing was carried out using an Omnicure series 1500 lamp 320-500 nm light source $\left(17 \mathrm{~mW} / \mathrm{cm}^{2}\right.$, power $\left.2.04 \mathrm{~J} / \mathrm{cm}^{2}\right)$. Samples for TGA and FTIR characterisation were cured for $120 \mathrm{~s}$. Hydrogels cured using visible light $\left(400-1300 \mathrm{~nm}, 50 \mathrm{~mW} / \mathrm{cm}^{2}\right)$ were irradiated for $150 \mathrm{~s}$ in the presence of $0.005 \%$ EY (w/v) and $0.1 \%$ TEOA (v/v) (see Table 3). Hydrogels were characterised by FTIR-ATR after dehydration (Figure S12), confirming the retention of the expected chemical structure and combination with bands associated with the crosslinker (poly(ethylene glycol) dithiol; CO stretching vibration at $\left.1050-1100 \mathrm{~cm}^{-1}\right)$. 
Table 1. The concentrations of the components used to generate gels from P1-P3 in molar concentration and $\mathrm{mg} / \mathrm{mL}$. Gels were made using thiol:ene $0.5: 1 \mathrm{~mol}$ ratio, $5 \mathrm{~mol} \%$ photoinitiator and $120 \mathrm{~s}$ UV exposure $\left(17 \mathrm{~mW} / \mathrm{cm}^{2}\right)$. Average modulus $(\mathrm{kPa})$ and average time taken to reach maximum storage modulus $\left(\mathrm{G}_{\mathrm{t}}\right)$ have been reported (from experiments carried out at $\mathrm{pH}$ 7.4).

\begin{tabular}{lcccccccc}
\hline Gel & $\begin{array}{c}\text { Alkene } \\
\text { conc } \\
(\mathbf{m M})\end{array}$ & $\begin{array}{c}\text { Thiol } \\
\text { conc }^{n} \\
(\mathrm{mM})\end{array}$ & $\begin{array}{c}\text { Thiol:ene } \\
\text { ratio }\end{array}$ & $\begin{array}{c}\text { Alkene } \\
(\mathrm{mg} / \mathrm{mL})\end{array}$ & $\begin{array}{c}\text { PEGDT } \\
(\mathrm{mg} / \mathrm{mL})\end{array}$ & $\begin{array}{c}\text { IRG 2959 } \\
(\mathrm{mg} / \mathrm{mL})\end{array}$ & $\begin{array}{c}\text { Modulus } \\
(\mathrm{kPa})\end{array}$ & $\begin{array}{c}\mathbf{G}_{\mathrm{t}} \\
(\mathbf{s})\end{array}$ \\
\hline P1s2 & 90 & 45 & $0.5: 1$ & 18.2 & 22.5 & 0.51 & No gel & - \\
\hline P1s3 & 135 & 67.5 & $0.5: 1$ & 27.3 & 33.8 & 0.76 & 0.480 & 101 \\
\hline P1s4 & 180 & 90 & $0.5: 1$ & 36.4 & 45 & 1.01 & 2.35 & 100 \\
\hline P1s5 & 225 & 112.5 & $0.5: 1$ & 45.5 & 56.3 & 1.27 & 7.47 & 97 \\
\hline P2s2 & 90 & 45 & $0.5: 1$ & 60.7 & 22.5 & 0.51 & 0.429 & 100 \\
\hline P2s3 & 135 & 67.5 & $0.5: 1$ & 91.1 & 33.8 & 0.76 & 5.11 & 63 \\
\hline P2s4 & 180 & 90 & $0.5: 1$ & 121.5 & 45 & 1.01 & 11.09 & 62 \\
\hline P2s5 & 225 & 112.5 & $0.5: 1$ & 151.8 & 56.3 & 1.27 & 16.38 & 60 \\
\hline P3s2 & 90 & 45 & $0.5: 1$ & 19.2 & 22.5 & 0.51 & 0.155 & 118 \\
\hline P3s3 & 135 & 67.5 & $0.5: 1$ & 28.8 & 33.8 & 0.76 & 1.41 & 111 \\
\hline P3s4 & 180 & 90 & $0.5: 1$ & 38.4 & 45 & 1.01 & 5.3 & 107 \\
\hline P3s5 & 225 & 112.5 & $0.5: 1$ & 48.0 & 56.3 & 1.27 & 11.08 & 97 \\
\hline P4s2 & 90 & 45 & $0.5: 1$ & 154.7 & 22.5 & 0.51 & 3.22 & 112 \\
\hline P4s3 & 135 & 67.5 & $0.5: 1$ & 232.0 & 33.8 & 0.76 & 17.75 & 111 \\
\hline P4s4 & 180 & 90 & $0.5: 1$ & 309.3 & 45 & 1.01 & No gel & - \\
\hline P4s5 & 225 & 112.5 & $0.5: 1$ & 386.7 & 56.3 & 1.27 & No gel & -
\end{tabular}

Table 2 The concentration of the components used to generate gels from P5-P7 in molar concentration and mg/mL. Gels were generated using $120 \mathrm{~s}$ UV exposure exposure $\left(17 \mathrm{~mW} / \mathrm{cm}^{2}\right)$. Average modulus $(\mathrm{kPa})$ and average time taken to reach maximum storage modulus $\left(\mathrm{G}_{\mathrm{t}}\right)$ are also reported (from experiments carried out at $\mathrm{pH}$ 7.4).

\begin{tabular}{lcccccccc}
\hline Gel & $\begin{array}{c}\text { Alkene } \\
\text { conc }^{n} \\
(\mathrm{mM})\end{array}$ & $\begin{array}{c}\text { Thiol } \\
\text { conc }^{\text {n }} \\
(\mathrm{mM})\end{array}$ & $\begin{array}{c}\text { Thiol:ene } \\
\text { ratio }\end{array}$ & $\begin{array}{c}\text { Alkene } \\
(\mathrm{mg} / \mathrm{mL})\end{array}$ & $\begin{array}{c}\text { PEGDT } \\
(\mathrm{mg} / \mathrm{mL})\end{array}$ & $\begin{array}{c}\text { IRG 2959 } \\
(\mathrm{mg} / \mathrm{mL})\end{array}$ & $\begin{array}{c}\text { Modulus } \\
(\mathrm{kPa})\end{array}$ & $\begin{array}{c}\mathrm{G}_{\mathrm{t}} \\
(\mathbf{s})\end{array}$ \\
\hline P55 & 2.35 & 1.5 & $0.64: 1$ & 5 & 0.65 & 0.17 & 0.189 & 109 \\
\hline P5 $_{10}$ & 4.7 & 3.0 & $0.64: 1$ & 10 & 1.3 & 0.33 & 0.465 & 89 \\
\hline P5 $_{20}$ & 9.4 & 6.0 & $0.64: 1$ & 20 & 2.6 & 0.67 & 1.929 & 85 \\
\hline P6 $_{\text {uv }}$ & 5.2 & 5.2 & $1: 1$ & 10 & 2.6 & 0.064 & 0.624 & 41 \\
\hline P7 & 4.85 & 4.85 & $1: 1$ & 10 & 2.42 & 0.064 & 0.706 & 37 \\
\hline
\end{tabular}

Table 3 The concentration of components used to generate gels from P6-P7 via visible light mediated photo-initiation, in molar concentrations and $\mathrm{mg} / \mathrm{mL}$. Gels were cured for $120 \mathrm{~s}$ with visible light exposure $\left(50 \mathrm{~mW} / \mathrm{cm}^{2}\right)$ in the presence of $0.1 \mathrm{v} / \mathrm{v} \%$ TEOA. Average modulus $(\mathrm{kPa})$ and average time taken to reach maximum storage modulus (Gt) are also reported (from experiments carried out at $\mathrm{pH} 7.4$ ).

\begin{tabular}{lcccccccc}
\hline Gel & $\begin{array}{c}\text { Alkene } \\
\text { conc }^{n} \\
(\mathrm{~m})\end{array}$ & $\begin{array}{c}\text { Thiol } \\
\text { conc }^{n}\end{array}$ & $\begin{array}{c}\text { Thiol:ene } \\
\text { ratio }\end{array}$ & $\begin{array}{c}\text { Alkene } \\
(\mathrm{m})\end{array}$ & $\begin{array}{c}\text { PEGDT } \\
(\mathrm{mg} / \mathrm{mL})\end{array}$ & $\begin{array}{c}\text { EY } \\
(\mathbf{w} / \mathbf{m} \%)\end{array}$ & $\begin{array}{c}\text { Modulus } \\
(\mathbf{k P a})\end{array}$ & $\begin{array}{c}\mathbf{G}_{\mathrm{t}} \\
(\mathbf{s})\end{array}$ \\
\hline P6EY & 5.17 & 5.2 & $1: 1$ & 10 & 2.6 & 0.005 & 0.519 & 69 \\
\hline P7EY & 4.85 & 4.85 & $1: 1$ & 10 & 2.42 & 0.005 & 0.255 & 101
\end{tabular}


Cell culture in hydrogels. HUVECs (Lonza, C2519A) were routinely grown in EBM-2 supplemented with ECGF. For fibroblast culture, HCA2 dermal fibroblasts were used ${ }^{42}$. Cells were routinely grown in DMEM supplemented with 10\% FBS, $1 \%$ penicillin streptomycin and $1 \%$ glutamine. The medium was changed every $2-3$ days and cells were sub-cultured each week using trypsin/versene. Cells were maintained at $37^{\circ} \mathrm{C}$ in a humidified atmosphere containing $5 \% \mathrm{CO}_{2}$. Hydrogels for cell culture were generated from corresponding polymer solutions in PBS (refer to Table 4). Solutions in PBS were filtered through a $0.2 \mu \mathrm{m}$ supor membrane pore for sterilisation. Cells were added (HUVECs passage 2-5, 1 million cells/mL gel; dermal fibroblasts, 0.5 million cells $/ \mathrm{mL}$ gel) and cured using UV light $\left(120 \mathrm{~s}, 17 \mathrm{~mW} / \mathrm{cm}^{2}\right.$, power $2.04 \mathrm{~J} / \mathrm{cm}^{2}$ ). Gels with 3D encapsulated cells were washed with PBS and medium before adding medium and incubation for $24 \mathrm{~h}$. The medium used for HUVECs was EBM-2 and for dermal fibroblasts was DMEM. Live/dead assays were performed on the 3D encapsulated cells at $24 \mathrm{~h}$ to study the cell viability. Cells were stained green with calcein $(0.5 \mu \mathrm{L} / \mathrm{mL})$ and red with ethidium homodimer-1 $(2 \mu \mathrm{L} / \mathrm{mL})$ in medium (serum-free) for 20 minutes, washed with medium and incubated 15 minutes before imaging. Epifluorescence images were produced using 10x objective and analysed using Image J. Penicillin streptomycin $(5000 \mathrm{U} / \mathrm{mL})$, Calcein was obtained from life technologies. FBS, South American Origin was purchased from Labtech. DMEM and calcein were obtained from life technologies. L-glutamine $(200 \mathrm{mM})$, versene, trypsin $(0.25 \%)$ phenol red and ethidium homodimer-1.were obtained from Thermo Fisher Scientific. HUVECs medium EBM-2 was purchased from Lonza. Custom peptides GCGGRGDSPG (RGD) and GCRDVPMS $\downarrow$ MRGGDRCG (VPM) ( $\downarrow$ indicates the cleavage site) were purchased from Proteogenix, France. 
Table 4 The concentration of the components used to generate P2 gels in molar concentration and weight percent. Gels were generated using a thiol:ene 0.5:1 ratio (for polymer and crosslinkers), $10 \mathrm{~mol} \% \mathrm{RGD}, 0.5 \mathrm{~mol} \% \mathrm{PI}$ and $120 \mathrm{~s}$ UV exposure.

\begin{tabular}{ccccccccc}
\hline $\begin{array}{c}\text { Gel } \\
\text { VPM:PEGDT }\end{array}$ & $\begin{array}{c}\text { Alkene } \\
\text { concn } \\
(\mathrm{mM})\end{array}$ & $\begin{array}{c}\text { Thiol } \\
\text { concn } \\
(\mathrm{mM})\end{array}$ & $\begin{array}{c}\text { Thiol-ene } \\
\text { ratio }\end{array}$ & $\begin{array}{c}\text { P2 } \\
(\mathrm{mg} / \mathrm{mL})\end{array}$ & $\begin{array}{c}\text { PEGDT } \\
(\mathrm{mg} / \mathrm{mL})\end{array}$ & $\begin{array}{c}\text { VPM } \\
(\mathrm{mg} / \mathrm{mL})\end{array}$ & $\begin{array}{c}\text { RGD } \\
(\mathrm{mg} / \mathrm{mL})\end{array}$ & $\begin{array}{c}\text { IRG 2959 } \\
(\mathrm{mg} / \mathrm{mL})\end{array}$ \\
\hline P2s3 & 135 & 67.5 & $0.5: 1$ & 91.1 & 33.8 & 0 & 12 & 0.76 \\
P2s4 & 135 & 67.5 & $0.5: 1$ & 91.1 & 33.8 & 0 & 12 & 0.76 \\
P2s5 & 135 & 67.5 & $0.5: 1$ & 91.1 & 33.8 & 0 & 12 & 0.76 \\
P2s3 100:0 & 135 & 67.5 & $0.5: 1$ & 91.1 & 0 & 57.3 & 12 & 0.76 \\
P2s3 75:25 & 135 & 67.5 & $0.5: 1$ & 91.1 & 8.5 & 42.9 & 12 & 0.76 \\
P2s3 50:50 & 135 & 67.5 & $0.5: 1$ & 91.1 & 16.9 & 28.6 & 12 & 0.76 \\
P2s4 75:25 & 180 & 90 & $0.5: 1$ & 121.5 & 11.3 & 57.3 & 16 & 1.01 \\
P2s5 75:25 & 225 & 112.5 & $0.5: 1$ & 151.8 & 14.1 & 71.6 & 19 & 1.27 \\
\hline
\end{tabular}

\section{Results and dicussion}

Effect of the molecular environment on thiol-ene coupling efficiency. Given the importance of the protonation state of thiols to the formation of thiyl radicals ${ }^{24,43}$, we first investigated the impact of $\mathrm{pH}$ on coupling efficiencies to the model thiol acetyl cysteine to a range of alkene-functionalised hydrophilic polymers (with thiol:olefin ratios of 1:1). We selected these polymers based on their neutrality (for the poly(2-alkyl-2-oxazoline) polymer P2) and their charge (positively charged as for the quaternized poly(dimethylaminoethyl methacrylate) P1 and negatively charged for the maleic anhydride copolymer P3, the functionalised poly(acrylic acid) P4 and carboxymethyl cellulose P5; see Scheme 1). Polyelectrolytes such as poly(acrylic acid), carboxymethyl cellulose and hyaluronic acid are often used as backbones for the formation of hydrogels via thiol-ene chemistry. By selecting a range of poly(anions) with a range of charge density (P3-P5), we aimed to investigate how such electrostatic environment would impact on thiol-ene coupling. 

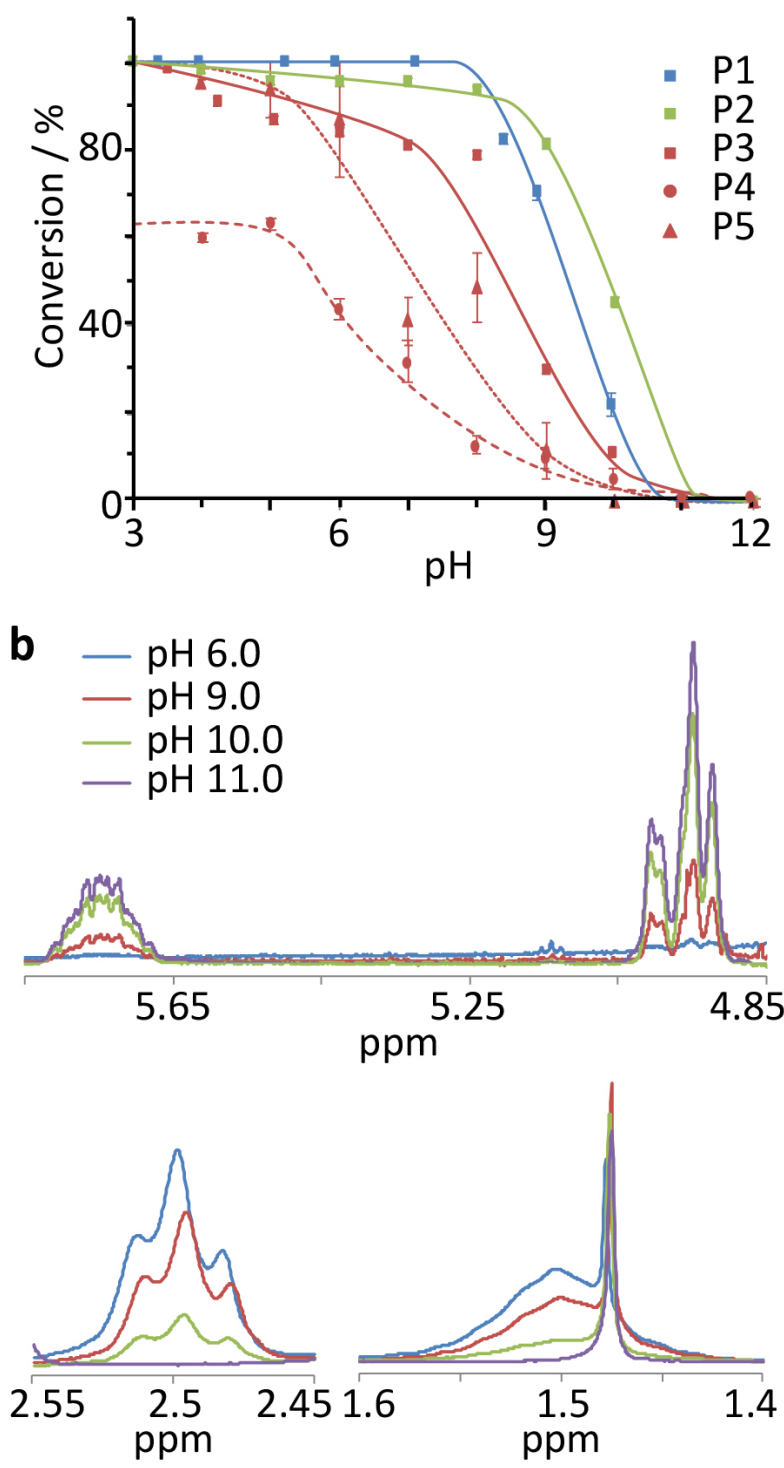

Figure 2. a) Impact of the backbone chemistry and $\mathrm{pH}$ of the reaction milieu on thiol-ene conversion with $N$-acetyl $L$ -

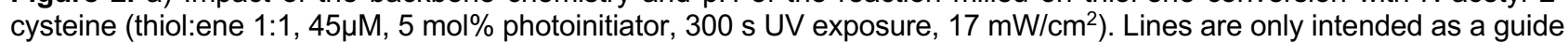
for the eye. b) ${ }^{1} \mathrm{H}$ NMR spectra for the thiol-ene reaction of polymer $\mathbf{P 2}$ with $\mathrm{N}$-acetyl $L$-cysteine, focusing on the alkene protons and those associated with the formation of thioether, at different $\mathrm{pH}$.

To mimic the environment typically used for the in situ formation of hydrogels for cell encapsulation or tissue engineering, thiol-ene radical coupling was carried out in deuterated phosphate buffer saline and monitored by ${ }^{1} \mathrm{H}$ NMR (Figure $2 \mathrm{a}$ and b, Scheme S6 and Figure S11) and initiated by Irgacure 2959. Advancement of these reactions at different $\mathrm{pH}$ was quantified via the integration of peaks associated with protons adjacent to the thiol and formed thioeter, compared to those of alkene protons. For P1 and P2, coupling was found 
to be efficient (> $95 \%$ ) up to $\mathrm{pH} 7.0$, prior to sharp decrease at higher $\mathrm{pH}$, due to the predominance of the thiolate forms of acetyl cysteine in basic conditions (pKa of 9.5 ${ }^{24,44}$ ). This is consistent with coupling efficiencies previously reported at different $\mathrm{pH}$ in PBS for model thiol-ene coupling reactions ${ }^{24}$. For terminal olefins, coupling was found to be efficient at low to neutral $\mathrm{pH}$ prior to sharply decreasing, depending on the $\mathrm{pKa}$ of the thiol involved. Hence it was identified that terminal cysteines are poorer anchors for radical thiol-ene coupling than acetyl or non-terminal cysteines, due to the reduction of their pKa. Consistent with this report, the polycation $\mathbf{P 1}$ displayed high reaction efficiencies as the olefin is sufficiently distant from the ammonium group to avoid overlap of the single occupied molecular orbital, centered on the carbon radical in the transition state, with the ammonium residue ${ }^{24}$

In contrast, coupling of acetyl cysteine to negatively charged polymers was substantially reduced (Figure 2a). Thiol-ene reaction efficiency was above $80 \%$ at $\mathrm{pH}$ below 7.0 for $\mathbf{P 3}$ and P5, below the coupling observed for P1 and P2. However, the striking reduction in thiolene efficiency observed at higher $\mathrm{pH}(>$ 8.0-9.0) for $\mathbf{P} 1$ and $\mathbf{P} 2$ occurred at lower $\mathrm{pH}$ in the case of P3 and P5. Strikingly, thiol-ene efficiency to the pentenyl-functionalised poly(acrylic acid) $\mathbf{P} 4$ was reduced to $60 \%$ at $\mathrm{pH} 4.0-5.0$ and the drop observed at higher $\mathrm{pH}$ occurred as early as $\mathrm{pH} 6.0$, with efficiencies below $30 \%$ at $\mathrm{pH}$ above 7.0 . Therefore, an increase in the density of carboxylate groups is clearly associated with a reduction in thiol-ene efficiency. Despite local $\mathrm{pH}$ effects, which will result in a significant level of protonation even at neutral $\mathrm{pH}^{45,46}$, a high negative potential is expected within polyanionic electrolytes. As a result, this local increase in negative charge density may alter the diffusion of negatively charged small molecules, such as acetyl cysteine, and prevent accessibility to alkene residues. 

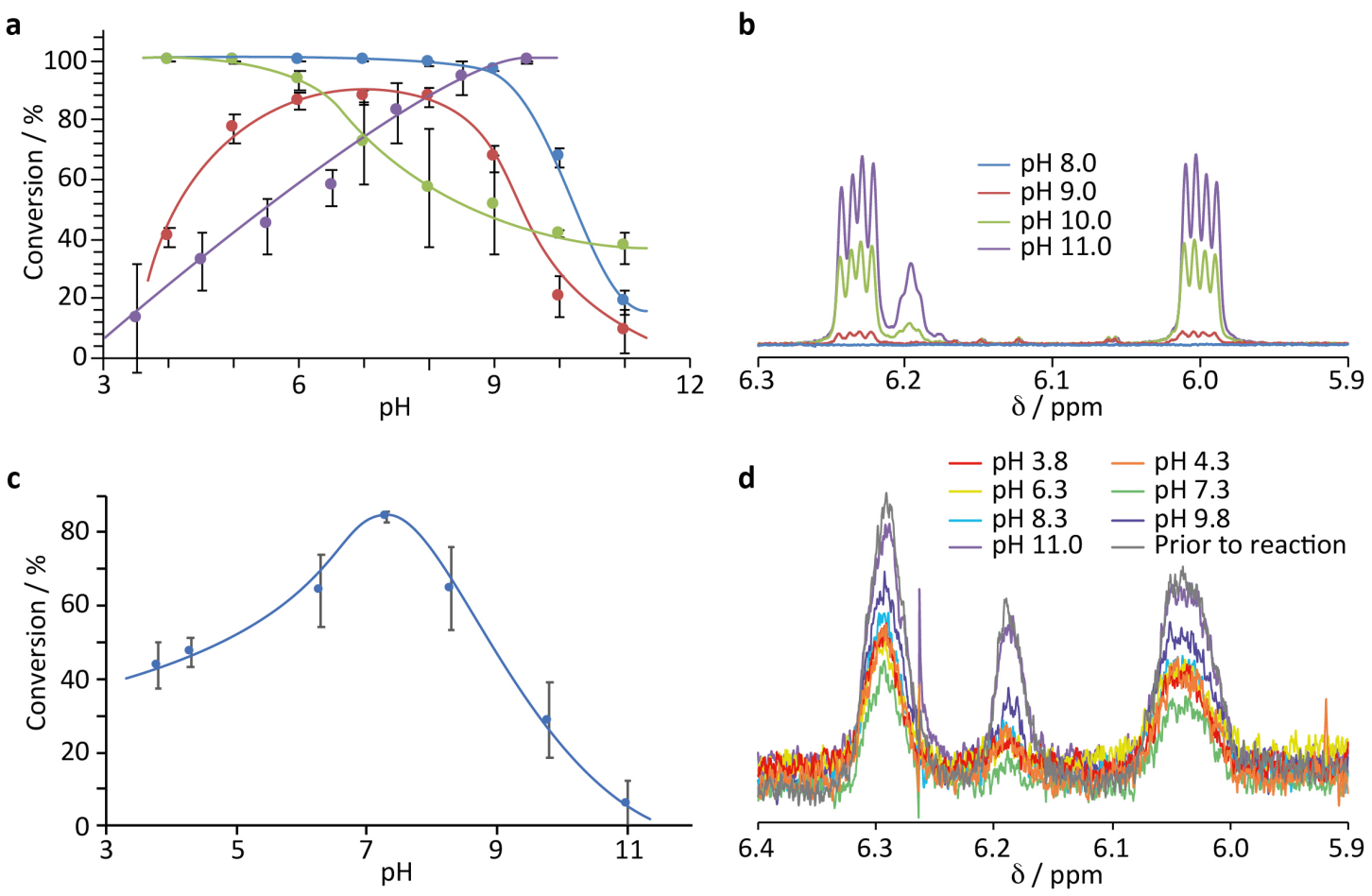

Figure 3. a) Series of alkene reacted with $\mathrm{N}$-acetyl-L-cysteine (Thiol:ene 1:1, $45 \mu \mathrm{M}$ ). With UV irradiation: 5 mol\% Irgacure 2959, $300 \mathrm{~s}$ exposure at $17 \mathrm{~mW} / \mathrm{cm}^{2}$. Blue, 5-Norbornene-2-carboxylic acid; Green, norbornene derivative 1. With visible light irradiation: $0.005 \%(\mathrm{w} / \mathrm{v})$ Eosin $\mathrm{Y}$ and $0.1 \%(/ \mathrm{v})$ TEOA, $300 \mathrm{~s}$ exposure at $50 \mathrm{~mW} / \mathrm{cm}^{2}$. Red, 5-Norbornene-2carboxylic. For Michael addition, PEG acrylate solutions were mixed with N-acetyl-L-cysteine solutions and allowed to react for $5 \mathrm{~min}$ prior to NMR characterisation. Purple, PEG acrylate. Lines are only intended as a guide for the eye. b) Examples of ${ }^{1} \mathrm{H}$ NMR spectra (alkene peaks only) for the thiol-norborene reaction (UV initiated) between 5-Norbornene-2carboxylic acid and $\mathrm{N}$-acetyl-L-cysteine, at different $\mathrm{pH}$. c) Impact of $\mathrm{pH}$ on thiol-ene coupling between P6 (50 mg/mL, 90 $\mathrm{kDa}$ ) and $\mathrm{N}$-acetyl-L-cysteine (thiol:ene 1:1, $45 \mu \mathrm{M}, 5 \mathrm{~mol} \%$ photoinitiator, $300 \mathrm{~s}$ UV exposure, $17 \mathrm{~mW}^{\mathrm{c}} \mathrm{cm}^{2}$ ). d) Corresponding examples of ${ }^{1} \mathrm{H}$ NMR spectra of alkene (norbornene).<smiles>C=CC(=O)OCCOC</smiles>

Scheme 2. Chemical structure of the different alkenes used in NMR experiments (see Figure 3).

\section{Impact of the molecular environment on thiol-ene coupling with nobornene}

derivatives. Norbornene-functionalised polymers have become widely used for the generation of hydrogels via thiol-ene radical coupling due to their high reactivity even in dilute conditions, in the presence of oxygen, and without significant unwanted chain growth radical polymerisation ${ }^{14}, 35,47,48$. These compounds can be introduced onto polymer backbones via ester, amide or ether bonds, however the impact of the local molecular environment and the $\mathrm{pH}$ of the media has not been systematically investigated in these systems. Hence we first examined the impact of the $\mathrm{pH}$ of the medium on thiol-ene radical 
coupling to norbornene derivatives (initiated with UV light irradiation and Irgacre 2959; see Figure $3 a$ and b). Similarly to the coupling of acetyl cysteine to non-activated terminal olefins, we observed high reaction effiencies in the case of 5-Norbornene-2-carboxylic acid at low to neutral $\mathrm{pH}$, followed by a marked decrease at higher $\mathrm{pH}$. However, efficiencies above $99 \%$ were retained up to $\mathrm{pH} 9.0$, likely due to the higher reactivity of this alkene, therefore enabling coupling even a $\mathrm{pH}$ for which significant thiolates are formed. In comparison, Michael addition of acetyl cysteine to a poly(ethylene glycol) acrylate was associated with a linear coupling efficiencies as the $\mathrm{pH}$ of the medium increased (Figure 3a), consistent with the importance of thiolates for this reaction. Surprisingly, a carbic anhydride derivative functionalised with hexane-1,6-diamine (compounds 1, Scheme 2) was found to display reduced efficiencies at lower $\mathrm{pH}$ (above $\mathrm{pH}$ 6.0). This may be due to a greater steric hindrance and potentially the increased hydrophobicity associated with this compound.

In addition to their high reactivity in thiol-ene coupling initiated by UV-active photoinitiators such as Irgacure 2959 and lithium phenyl-2,4,6-trimethylbenzoylphosphinate, reactive olefin-functionalised polymers have been cured via visible light initiated systems, for example using Eosin $\mathrm{Y}^{25,28,30}$. However, the impact of $\mathrm{pH}$ on this polymerisation system has not been studied. Therefore, we investigated the impact of Eosin $Y$ initiated visible light activated radical coupling of acetyl cysteine to norbornene carboxylic acid (Figure 3a). Similarly to UV-initiated systems, reactivities were high (above 87\%) within pH 6.0-8.0, confirming the potential of visible light curing for in situ hydrogel formation. Above this $\mathrm{pH}$ range, thiolates are again starting to dominate, leading to a reduction in coupling. However, below a pH of 6.0 , we also observed a significant decrease in efficiency, presumably due to the protonation of Eosin Y. Hence visible light activated thiol-ene coupling to norbornene residues is expected to be stable within a reasonably wide range of $\mathrm{pH}$, relevant to in situ cell encapsulation and loading within degradable hydrogels. 
Finally, we investigated the coupling of acetyl cysteine to the norbornene-functionalised carboxymethyl cellulose P6 (Figure 3c and d). As for other polyanions tested, thiol-ene coupling decreased drastically at elevated $\mathrm{pH}$ (8.0 and above), due to thiolate prevalence. Coupling was optimal at $\mathrm{pH} 7.4$, with efficiencies of $84 \%$. At lower $\mathrm{pH}$, a reduction of coupling down to $43 \%$ was also observed, in contrast to the radical thiol-ene coupling observed for P5 and the two low molar mass norbornene derivatives tested (Figure $3 a$ and b). The origin of this behaviour is unclear, but may be due to the more hydrophobic character of norbornene residues compared to pentene side chains, leading to more shielded structures as carboxymethyl cellulose protonates at lower $\mathrm{pH}$ and collapses. Overall, our results clearly demonstrate the strong impact that the molecular structure of polymer backbones, coupled to their pH-responsive behaviour and the acid-base properties of thiols and initiator molecules, play in determining radical thiol-ene tethering efficiencies.
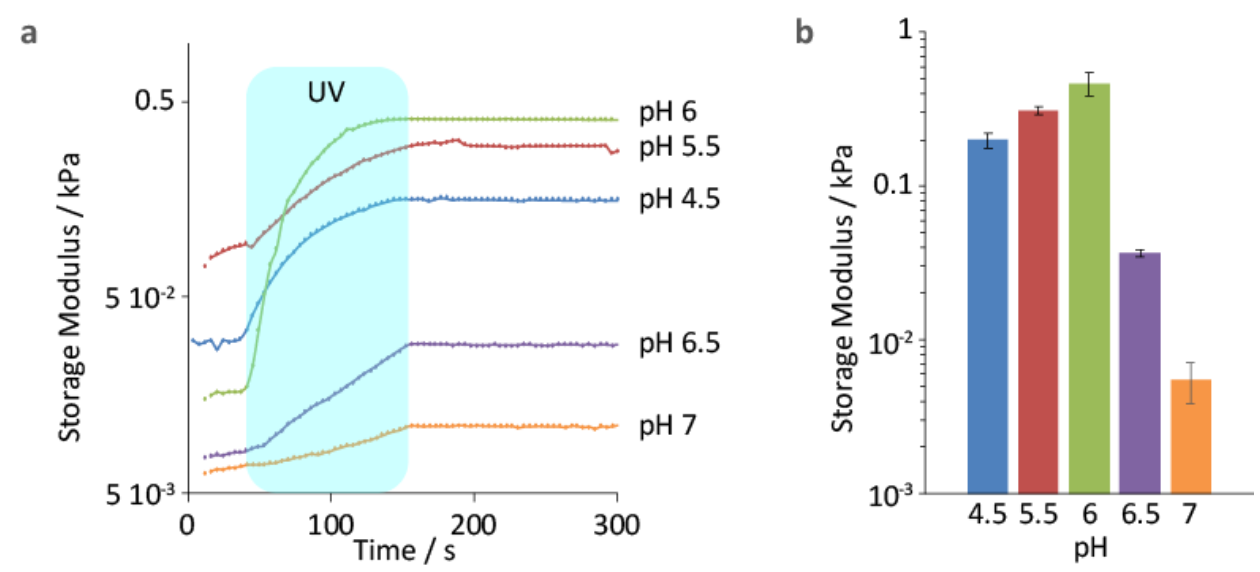

Figure 4. Charcaterisation of the shear mechanical properties of thiol-ene hydrogels based on P5 (10 mg/mL) and PEGDT, at different $\mathrm{pH}$. a) Evolution of the storage modulus as a function of time and (b) summary of the corresponding storage moduli measured at a frequency of $1 \mathrm{~Hz}$ and $1 \%$ strain. The thiol:ene ratio was $1: 1$ in all cases, the exposure was $120 \mathrm{~s}$ at $17 \mathrm{~mW} / \mathrm{cm}^{2}$ UV intensity, starting after $30 \mathrm{~s}$ of measurement (blue box). See Table 2 for further details.

\section{Impact of the pH of the medium on UV- and visible light initiated thiol-ene coupling.}

Having determined how the molecular environment impacts on thiol-ene coupling to a range of polymer backbones, we next investigated how such factors translated into changes in crosslinking and rheological properties of corresponding hydrogels. We first investigated the role of the $\mathrm{pH}$ on pentenyl-functionalised carboxymethyl cellulose P5, using photo-rheology. 
Hydrogel mixtures (100 $\mu \mathrm{L}$, containing P5, the crosslinker poly(ethylene glycol dithiol) (PEGDT) at a $1 / 2$ thiol/alkene) were placed between two methacrylate-functionalised coverslips fixed to the geometries of the rheometer, to ensure chemical coupling and effective stress transmission at the interface ${ }^{36}$, followed by irradiation with UV light (360 $\left.\mathrm{nm}\right)$. At $\mathrm{pH}$ 6.0, the storage shear modulus rose quickly following the start of photoinitiation and reached a plateau at $500 \mathrm{~Pa}$ (for a $10 \mathrm{mg} / \mathrm{mL}, 1 \mathrm{wt} \%$, gel) within $2 \mathrm{~min}$ of irradiation (Figure 4a). Although similar trends were observed at all $\mathrm{pH}$ tested, the ultimate modulus reached after 2 min of curing varied significantly with $\mathrm{pH}$ (Figures 4 and S14). At $\mathrm{pH}$ above 6.0, the modulus of the corresponding gels rapidly decreased below $100 \mathrm{~Pa}$ and gels above a $\mathrm{pH}$ of 7.4 failed to gel properly, mirroring the sharp decrease in coupling of acetyl cysteine to P5 at these $\mathrm{pH}$. At lower $\mathrm{pH}$, the storage shear moduli of hydrogels was more stable, although it reduced slightly from $464 \pm 80 \mathrm{~Pa}$ to $198 \pm 22 \mathrm{~Pa}$, perhaps reflecting conformational changes and associated reduction in the hydrodynamic diameter of carboxymethyl cellulose at lower $\mathrm{pH}$. Such changes in the conformation of polymer chains affects molecular diffusion, but could also have an impact on the degree of loop formation (and therefore network defects) resulting from increased intramolecular coupling.

Similarly, the norbornene-functionalised carboxymethyl cellulose and hyaluronic acid P6 and P7 displayed similar trends, with maxima in storage shear moduli near neutral $\mathrm{pH}$ (Figure 5). However, even at $\mathrm{pH} 11.0$, hydrogels retained moduli above $148 \pm 45 \mathrm{~Pa}$ and $184 \pm 22 \mathrm{~Pa}$ (for P6 and P7, respectively), in agreement with the residual coupling efficiency displayed at this $\mathrm{pH}$ (Figure 3c), compared to the absence of any reaction in the case of P5 at the same $\mathrm{pH}$ (Figure 2a). The functionalisation levels achieved for P5, P6 and P7 (13.4, 22.5 and $19.0 \%$, respectively) correspond to 137,215 and 91 alkene moieties per polymer chains, respectively. Hence, at neutral $\mathrm{pH}$, with a coupling efficiency of $88 \%$, P6 should display 189 crosslinks per chains, on average. At pH 11.0, with a coupling efficiency of 8.9 
$\%$, the number of crosslinks is predicted to decrease to 19 , a number still sufficient to sustain the formation of a macroscopic gel. In contrast, P5 should not support the formation of crosslinks at this $\mathrm{pH}$, based on its lack of reactivity with aceyl cysteine. Although reactivity with PEGDT is likely to differe to that of acetyl cysteine, due to reduction in thiol-ene efficiency observed for polymer-polymer coupling ${ }^{49}$, reactivity trends observed account for trends in shear mechanical properties of the resulting hydrogels. At lower $\mathrm{pH}$, the shear moduli of the hydrogels generated also decreased (Figure 5a), in line with the observed coupling efficiency measured at $\mathrm{pH}$ below 7.0 (Figure 3c). This phenomenon was comparable in the case of $\mathbf{P 6}$ and $\mathbf{P 7}$ to the reduction in modulus observed in the same $\mathrm{pH}$ range for P5. 


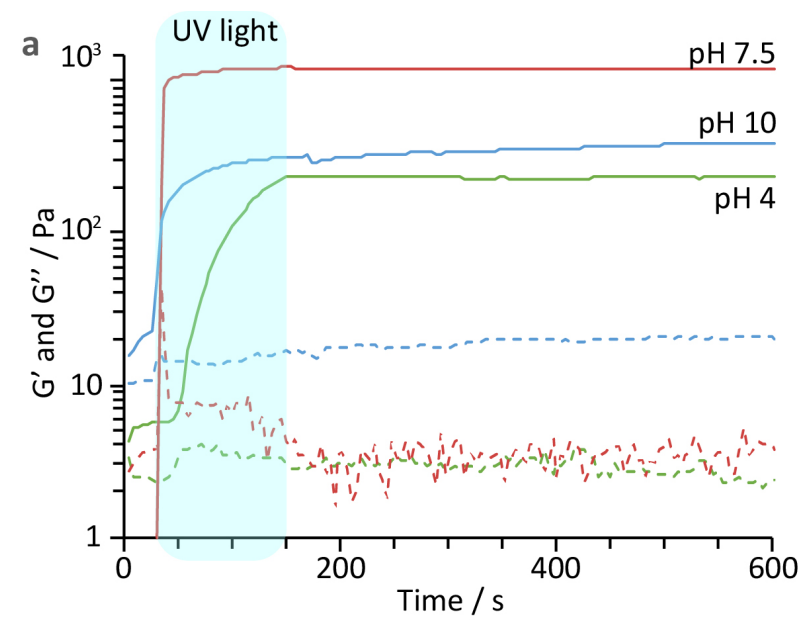

b
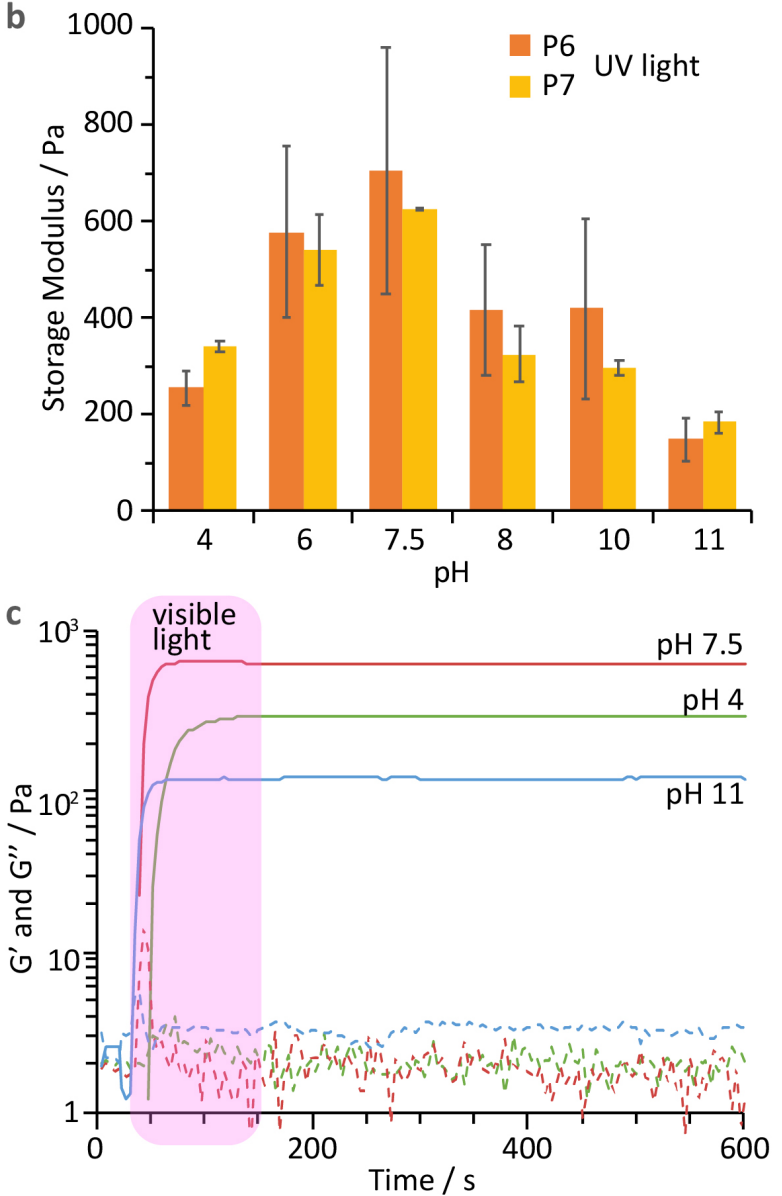

d

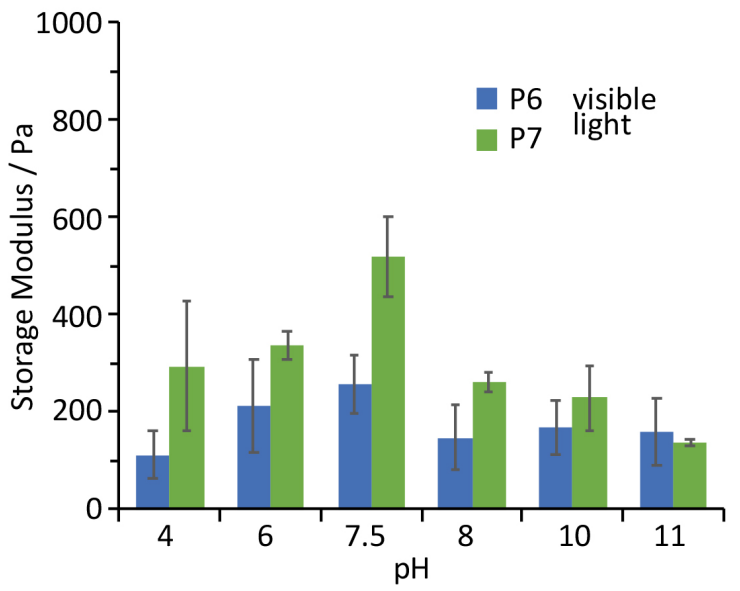

Figure 5. Charcaterisation of the shear mechanical properties of thiol-norbornene hydrogels based on P6 and P7 $(10 \mathrm{mg} / \mathrm{mL})$ and PEGDT, at different $\mathrm{pH}$. a) Evolution of the storage modulus as a function of time for curing of P6 with UV light at different $\mathrm{pH}$ and (b) summary of storage moduli measured at a frequency of $1 \mathrm{~Hz}$ and $1 \%$ strain at a wider range of $\mathrm{pH}$ for $\mathbf{P 6}$ and $\mathbf{P 7}$. The thiol:ene ratio was $1: 1$ in all cases, the exposure was $120 \mathrm{~s}$ at $17 \mathrm{~mW} / \mathrm{cm}^{2} \mathrm{UV}$ intensity, starting after $30 \mathrm{~s}$ of measurement (blue box). c) Evolution of the storage modulus as a function of time for curing of P7 with visible light at different $\mathrm{pH}$ and (d) summary of storage moduli measured at a frequency of $1 \mathrm{~Hz}$ and $1 \%$ strain at a wider range of $\mathrm{pH}$ for $\mathbf{P 6}$ and $\mathbf{P 7}$. The thiol:ene ratio was $1: 1$ in all cases, the exposure was $120 \mathrm{~s}$ at $50 \mathrm{~mW} / \mathrm{cm}^{2}$ visible intensity, starting after $30 \mathrm{~s}$ of measurement (purple box). See Tables 2 and 3 for further details. 
The crosslinking of P6 and P7 with visible light photo-initiation was next explored (Figure 5c and d). We compared these systems at identical polymer concentrations (10 mg/mL, $1 \mathrm{wt} \%$ ), PEGDT crosslinker concentration $(2.33 \mathrm{mg} / \mathrm{mL}$ for $\mathrm{P} 6$ and $3.45 \mathrm{mg} / \mathrm{mL}$ for $\mathrm{P} 7$, thiol:alkene 1:1). Similary to the UV-initiated system, with Eosin $Y$ and visible light initiation (400-1300 $\mathrm{nm})$, we observed maximum storage shear moduli at neutral $\mathrm{pH}(255 \pm 60$ and $519 \pm 82 \mathrm{~Pa}$ for P6 and P7 respectively). These moduli are comparable to those measured with UV-light initiation, in line with the comparable coupling efficiency measured for norbornene carboxylic acid with acetyl cysteine at neutral $\mathrm{pH}$ in both initiation conditions (Figure 3a). Similarly to UV-initiated systems, shear moduli decreased at higher and lower $\mathrm{pH}$, although remaining above $100 \mathrm{~Pa}$. This is in agreement with the coupling efficiencies observed on the same $\mathrm{pH}$ range. The moduli measured for $\mathbf{P 6}$ were overall lower than those measured for $\mathbf{P 7}$, perhaps reflecting difference in conformation between these two polymers (and therefore changes in the formation of loops not contributing to networks). All hydrogels displayed frequency sweep and stress relaxation profiles typical of elastomeric networks (Figure S15). Hence, our results indicate that visible light initiation displays a comparable efficiency to UV-initiated systems for norbornene derivatives. However, we point out that visible light initiation failed to promote thiol-ene coupling with non-activated alkenes such as pentenoic acid (with coupling efficiencies below $18 \%$ at all $\mathrm{pH}$ tested, using the same quantification protocole used for Figure 3a). Hence, this initiation system is found to be less permissive in terms of molecular structure and $\mathrm{pH}$ range, but to display comparable efficiencies at neutral $\mathrm{pH}$ with norbornene derivatives. 
P5
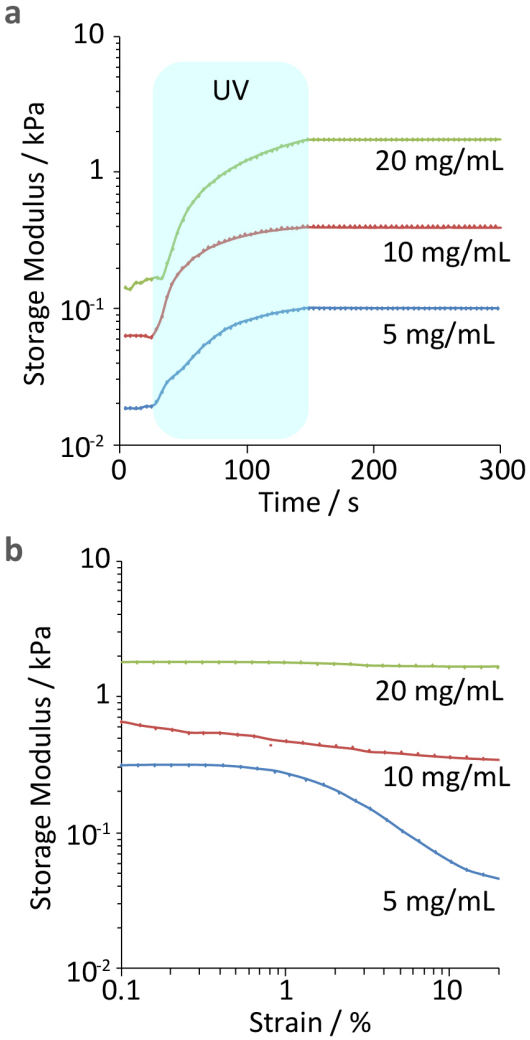

P2

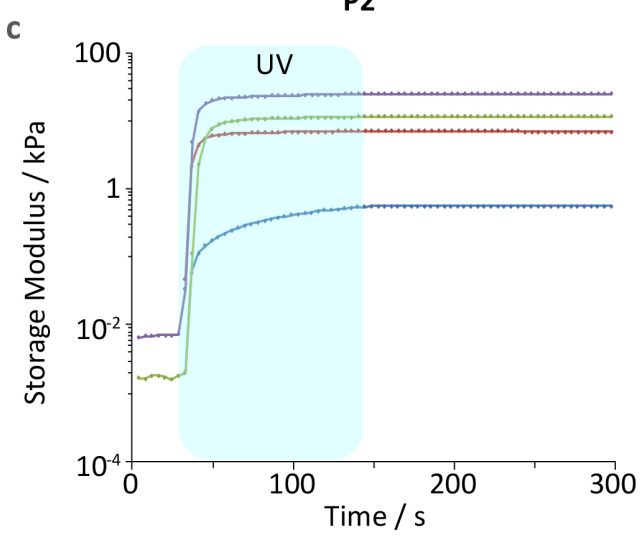

व

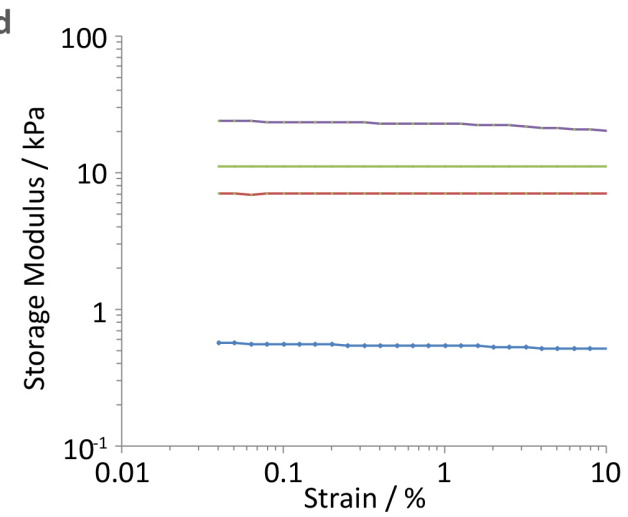

Figure 6. Charcaterisation of the shear mechanical properties of thiol-ene hydrogels based on P5 and P2 with PEGDT, at different polymer backbone concentrations. a) P5 gels at different concentrations. Evolution of the storage modulus as a function of time (frequency of $1 \mathrm{~Hz}$ and $1 \%$ strain) and (b) corresponding strain sweeps (frequency of $1 \mathrm{~Hz}$ ). The alkene/thiol ratio was kept at $1 / 1$ in all cases, the exposure was $120 \mathrm{~s}$ at $17 \mathrm{~mW} / \mathrm{cm}^{2} \mathrm{UV}$ intensity, starting after $30 \mathrm{~s}$ of measurement (blue box). c) Hydrodgels formed from P2 at different polymer backbone concentrations (blue, S2, 90 mM; red, S3, 135 mM; green, S4, 180 mM; purple, S5, $225 \mathrm{mM}$; see Table 1 for full details). Evolution of the storage modulus as a function of time (frequency of $1 \mathrm{~Hz}$ and $1 \%$ strain). d) Corresponding strain sweeps (frequency of $1 \mathrm{~Hz}$ ). The alkene/thiol ratio was kept at $2 / 1$ in all cases, the exposure was $120 \mathrm{~s}$ at $17 \mathrm{~mW} / \mathrm{cm}^{2} \mathrm{UV}$ intensity, starting after $30 \mathrm{~s}$ of measurement (blue box). See Tables 1 and 2 for further details.

Impact of the polymer composition and structure on hydrogel mechanics. Given the importance of polymer concentration on hydrogel mechanics, we confirmed that the macromolecule concentration significantly impacted the final moduli of thiol-ene hydrogels (Figure 6). Increasing the concentration of the neutral poly(2-alkyl-2-oxazoline) P2 from 22.5 to $56.3 \mathrm{mg} / \mathrm{mL}$ resulted in an increase in storage shear modulus from $430 \mathrm{~Pa}$ to $16.4 \mathrm{kPa}$ (Table 1). Similarly, increasing the concentration of the polyanionic carboxymethyl cellulose P5 from 5 to $20 \mathrm{mg} / \mathrm{mL}$ resulted in an increase in the storage shear modulus from $190 \mathrm{~Pa}$ to $1.93 \mathrm{kPa}$ (Table 2). Interestingly, although at an alkene concentration of $9.5 \mathrm{mM}$ P5 led to a modulus of $1.93 \mathrm{kPa}$, at a concentration nearly ten times higher $(90 \mathrm{mM}), \mathbf{P} 2$ led to a modulus of $430 \mathrm{~Pa}$ only. This may be due to some extent to a slight difference in thiol:alkene 
ratios $(0.64$ and 0.5 , respectively), but is also a direct reflection of the difference in macromolecular architecture of these two polymers. Hence, despite a molar mass of 1830 g/mol per alkene residue, significantly higher for P5 than P2 $686 \mathrm{~g} / \mathrm{mol}, 15 \%$ alkene functionalisation), which should lead to an increase in mesh size, P5 was significantly stiffer, even at a lower concentration. However, the total number of alkenes per chains of P5 (137, compared to 9 for P2) and the predicted number of crosslinks per chain (62, compared to 8.5 for P2) will be higher for the carboxymetyl cellulose based hydrogels. In comparison, at lower concentrations, comparable to those used for P5, P2 and P3 did not form macroscopic hydrogels. In addition, the more extended conformation expected from the negatively charged P5 and its higher overall molecular weight will promote the formation of more extended networks with fewer loop defects. Finally, the formation of secondary physical crosslinks, although not contributing significantly to network mechanics individually, may collectively result in a stiffening of associated materials. This is reflected in the increase in viscosity and shear moduli measured prior to crosslinking in the case of P5 (Figure 6a).

We next examined the impact of the positively charged P1 and the negatively charged P3 on the concentration dependent behaviour of corresponding hydrogels (Figure 7). In these cases too, the hydrogel storage shear modulus increased with the polymer concentration. However, at comparable polymer concentrations, the modulus of P1 and P3-based hydrogels was higher than that of P2 (e.g. 7.5 and $11.1 \mathrm{kPa}$ for 45 and $48 \mathrm{mg} / \mathrm{mL} \mathbf{P} 1$ and P3 gels compared to $430 \mathrm{~Pa}$ for $\mathbf{P} 2$ at $60 \mathrm{mg} / \mathrm{mL}$; see Table 1). Hence the concentration of alkene moieties was a better predictor of the modulus of these materials, considering the relatively comparable crosslinking efficiencies measured for these three polymers at neutral $\mathrm{pH}$ (Figure 2). Further differences in moduli achieved are likely due to overall polymer concentrations required, differences in molecular weight of the corresponding polymers and their molecular conformation (more elongated for densely charged polymers), as well as repulsions between polymer chains. For example, despite a high number of alkene moieties 
per chain for P1 (300 olefins per macromolecule), and a relatively high molecular weight (68 $\mathrm{kDa}$ ), it resulted in hydrogels with reduced storage shear moduli at the same alkene concentration.

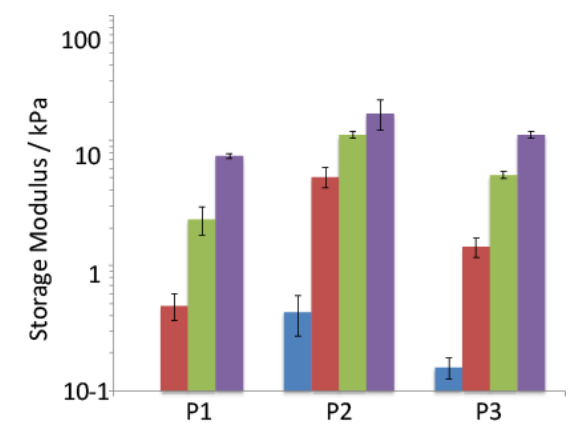

Figure 7. Summary of the storage moduli measured for gels based on backbones P1-P3, with different compositions (S2, blue; S3, red; S4, green; S5 purple). The alkene/thiol ratio was kept at 2/1 in all cases, the exposure was $120 \mathrm{~s}$ at 17 $\mathrm{mW} / \mathrm{cm}^{2}$ UV intensity, with $5 \mathrm{~mol} \%$ photoinitiator.

Cell encapsulation within thiol-ene based hydrogels. Having identified some of the factors regulating hydrogel formation via thiol-ene radical coupling, we then explored the use of these materials for cell encapsulation. We first examined the swelling of hydrogels P1-P5, quantified via the determination of water contents via TGA (Figure S13 and S16), owing to the importance of changes in water content after cell encapsulation on mechanical properties and cell survival ${ }^{29}$. Swelling levels correlated with the polymer contents introduced during the preparation of the solutions of precursors prior to gelation (Tables 1 and 2). Hence the relatively low polymer densities associated with P5 hydrogels studied led to very limited swelling levels (Figure S16). In addition, swellings were found to be more pronounced in deionised water, in agreement with the associated increased osmotic pressure. Overall, the swelling levels measured for P1-P5 remained below $20 \%$ and were considered reasonable for cell encapsulation.

To investigate eventual cytotoxic effects induced during encapsulation, human umbilical vein endothelial cells (HUVECs) were seeded in hydrogels generated from P1-P5 (Figure 8). As these gels were designed to display an excess of alkenes, we were able to introduce 
additional cysteine-bearing RGD peptides to promote cell adhesion. Viability levels were compared to those of cells cultured on 2D tissue culture plastic (Ctrl.). Cells encapsulated in hydrogels based on the polycationic P1 died rapidly, due to its strong electrostatic charge density able to disrupt cell membranes. However, most cells seeded in the other hydrogels appeared to survive after $24 \mathrm{~h}$ of culture. We note that even cells seeded in P5, which was formed at a slightly lower $\mathrm{pH}(\mathrm{pH}$ 6.0) to promote efficient network formation (prior to exchanging with medium shortly after curing of these hydrogels) remained viable. However, cells loaded in P4-based hydrogels displayed reduced viability levels, perhaps owing to the high charge density associated with this material and its stronger swelling, even in PBS (Figure S16). Considering the lack of cell-mediated degradability of these hydrogels, the lack of cell spreading was unsurprising.
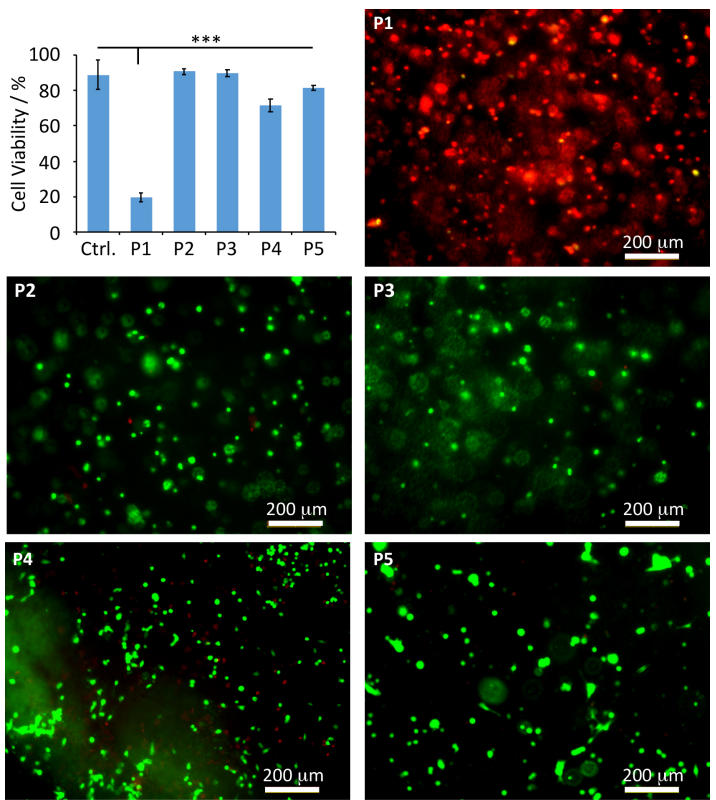

Figure 8. Viability of HUVECs encapsulated in non-degradable PEGDT crosslinked hydrogels with backbones P1-P5 after $24 \mathrm{~h}$ of culture (cell densities of 1 million cells $/ \mathrm{mL}$ ) and corresponding fluorescence microscopy images. Live cells were stained green and dead cells red. Gels P1-P3 were generated with alkene/thiol ratios of 2:1, $10 \mathrm{~mol} \%$ RGD, $5 \mathrm{~mol} \%$ photoinitiator and $120 \mathrm{~s}$ UV exposure. P4 and P5 were made with alkene ratio of 2:1, $10 \mathrm{~mol} \% \mathrm{RGD}, 5$ mol\% photoinitiator and $120 \mathrm{~s}$ UV. Gels were made at the $\mathrm{pH}$ relevant to biological conditions and showing good conversion levels (Figure 2): P1, pH 7.4; P2, pH 7.4; P3, pH 7.4; P4, pH 7 and P5, pH 6. 
We next examined the impact of hydrogel mechanics on cell viability, focusing on the poly(ethylene glycol) analogue P2-based system. HUVECs were seeded in hydrogels displaying shear storage moduli ranging from $430 \mathrm{~Pa}$ to $16.4 \mathrm{kPa}$ (see Table 1, entries P2s2$\mathrm{P} 2 \mathrm{s5}$ ) and cultured for $24 \mathrm{~h}$. Although cells remained rounded in these hydrogels (all were crosslinked with the non-degradable PEGDT) viabilities were high at all stiffnesses (Figure S17). To confirm the generality of these results, we investigated the viability of dermal fibroblasts in poly(2-ethyl-2-oxazoline) hydrogels with stiffnesses ranging from 5.1 to 16.4 $\mathrm{kPa}$ and observed again high viabilities in all conditions (Figure S18). When the degradability of these networks was increased by replacing PEGDT with a di-cystein peptide bearing the enzymatically cleavable VPM sequence, high viabilities were retained (Figure S18c). Therefore, our results demonstrate the potential of poly(2-oxazoline) based hydrogels to safely encapsulate cells in matrices with controlled mechanics and degradation. 


\section{Conclusions}

Thiol-ene based hydrogels are particularly attractive for cell encapsulation as the mild character of this crosslinking chemistry has minor impact on cell viability and can be triggered with UV as well as visible light. Our work indicates the importance of the molecular microenvironment on the efficiency of radical thiol-ene coupling. However, we find that thiolene efficiencies remain high at neutral $\mathrm{pH}$ for most polymer architectures tested, except those displaying particularly high negative charge densities. This was proposed to be due to changes in thiol densities and local diffusion, limiting coupling, although deprotonation of thiols by basic residues of the polymer backbone cannot be excluded. Therefore, the impact of peptide chemistry on such diffusion and associated polymer coupling and crosslinking should be investigated more systematically, to fully determine the freedom with which peptide sequences can be engineered independently of thiol-ene radical coupling. We also found that thiol-ene efficiencies in visible light-initiated systems remain high on a sufficiently broad $\mathrm{pH}$ range centered around neutral $\mathrm{pH}$, providing that activated norbornene moieties are used, with minimal impact on the mechanics of the resulting matrices. The non-activated olefins tested were found to display very limited reactivity using this initiating system. Visible light initiation remains incompatible with classic fully supplemented cell culture media though and requires the use of media unsupplemented with phenol red, or PBS, at least for curing. Beyond a more thorough investigation of the impact of peptide sequence on polymer coupling and hydrogel crosslinking, the impact of molecular structure on the coupling of other macromolecules, mimicking other properties of the extra-cellular matrix or conferring additional properties such as drug delivery or nanoparticle coupling should be characterised systematically. 


\section{Supporting information}

The Supporting Information is available free of charge at https://pubs.acs.org/doi/. Additional NMR, FTIR, GPC, TGA, rheology and cell viability characterisation.

\section{Author Information}

Corresponding Author.

*E-mail: j.gautrot@qmul.ac.uk.

Notes.

The authors declare no competing financial interest.

\section{Acknowledgment}

B.C. thanks Queen Mary, University of London for her PhD studentship. L.W. thanks the Chinese Scholarship Council (grant no 201506550007). This work was supported by European Research Council (ProLiCell, 772462). 


\section{References}

1. Caliari, S. R.; Burdick, J. A., A practical guide to hydrogels for cell culture. Nat. Methods 2016, 13 (5), 405-414.

2. $\mathrm{Xu}, \mathrm{Z}$; ; Bratlie, K. M., Click chemistry and material selection for in situ fabrication of hydrogels in tissue engineering applications. ACS Biomater. Sci. Eng. 2018, 4, 2276-2291.

3. Kharkar, P. M.; Rehman, M. S.; Skeens, K. M.; Maverakis, E.; Kloxin, A. M., Thiolene click hydrogels for therapeutic delivery. ACS Biomater. Sci. Eng. 2016, 2 (2), 165-179.

4. Jiang, Y.; Chen, J.; Deng, C.; Suuronen, E. J.; Zhong, Z., Click hydrogels, microgels and nanogels: Emerging platforms for drug delivery and tissue engineering. Biomaterials 2014, 35, 4969-4985.

5. Colak, B.; di Cio, S.; Gautrot, J. E., Biofunctionalised patterned polymer brushes via thiol-ene coupling for the control of cell adhesion and the formation of cell arrays. Biomacromolecules 2018, 19 (5), 1445-1455.

6. Tan, K. Y.; Ramstedt, M.; Colak, B.; Huck, W. T. S.; Gautrot, J. E., Study of thiolene chemistry on polymer brushes and application to surface patterning and protein adsorption Polym. Chem. 2016, 7, 979-990.

7. Ahmad, N.; Colak, B.; Gibbs, M. J.; Zhang, D. W.; Gautrot, J. E.; Watkinson, M.; Becer, C. R.; Krause, S., Peptide cross-linked poly(2-oxazoline) as a sensor material for the detection of proteases with a quartz crystal microbalance. Biomacromolecules 2019, 7, 2506-2514.

8. Ahmad, N.; Colak, B.; Zhang, D. W.; Gibbs, M. J.; Watkinson, M.; Becer, C. R.; Gautrot, J. E.; Krause, S., Peptide cross-linked poly(ethylene glycol) hydrogel films as biosensor coatings for the detection of collagenase. Sensors 2019, 19, 1677.

9. Gould, S. T.; Darling, N. J.; Anseth, K. S., Small peptide functionalized thiol-ene hydrogels as culture substrates for understanding valvular interstitial cell activation and de novo tissue deposition. Acta Biomater 2012, 8, 3201-3209.

10. Neumann, A. J.; Quinn, T.; Bryant, S. J., Nondestructive evaluation of a new hydrolytically degradable and photo-clickable PEG hydrogel for cartilage tissue engineering. Acta. Biomaterialia 2016, 39, 1-11.

11. Wade, R. J.; Bassin, E. J.; Gramlich, W. M.; Burdick, J. A., Nanofi brous Hydrogels with Spatially Patterned Biochemical Signals to Control Cell Behavior. Adv. Mater. 2015, 27 (8), 1356-1362.

12. Cai, S.; Liu, Y.; Shu, X. Z.; Prestwich, G. D., Injectable glycosaminoglycan hydrogels for controlled release of human basic fibroblast growth factor. Biomaterials 2005, 26, 6054-6067.

13. Fu, Y.; Xu, K.; Zheng, X.; Giacomin, A. J.; Mix, A. W.; Kao, W. J., 3D cell entrapment in crosslinked thiolated gelatin-poly(ethylene glycol) diacrylate hydrogels. Biomaterials 2012, 33, 48-58.

14. Gramlich, W. M.; Kim, I. L.; Burdick, J. A., Synthesis and orthogonal photopatterning of hyaluronic acid hydrogels with thiol-norbornene chemistry. Biomaterials 2013, 34, 9803-9811.

15. Khetan, S.; Guvendiren, M.; Legant, W. R.; Cohen, D. M.; Chen, C. S.; Burdick, J. A., Degradation-mediated cellular traction directs stem cell fate in covalently crosslinked three-dimensional hydrogels. Nat. Mater. 2013, 12, 458-465.

16. Trappmann, B.; Baker, B. M.; Polacheck, W. J.; Choi, C. K.; Burdick, J. A.; Chen, C. S., Matrix degradability controls multicellularity of 3D cell migration. Nat. Commun. 2017, 8, 371.

17. Ruskowitz, E. R.; DeForest, C. A., Proteome-wide Analysis of Cellular Response to Ultraviolet Light for Biomaterial Synthesis and Modification. ACS Biomater. Sci. Eng. 2019, 5 (5), 2111-2116. 
18. Costa, P.; Gautrot, J. E.; Connelly, J., Directing cell migration using micropatterned and dynamically adhesive polymer brushes. Acta Biomater 2014, 10 (6), 2415-2422.

19. Marklein, R. A.; Burdick, J. A., Spatially controlled hydrogell mechanics to modulate stem cell interactions. Soft Matter 2010, 6, 136-143.

20. Cramer, N. B.; Bowman, C. N., Kinetics of thiol-ene and thiol-acrylate photopolymerizations with real-time fourier transform infrared. J. Polym. Sci., A: Polym. Chem. 2001, 39, 3311-3319.

21. Cramer, N. B.; Reddy, S. K.; O'Brien, A. K.; Bowman, C. N., Thiol-ene photopolymerization mechanism and rate limiting step changes for various vinyl functional group chemistries. Macromolecules 2003, 36 (21), 7964-7969.

22. Reddy, S. K.; Cramer, N. B.; Bowman, C. N., Thiol-vinyl mechanisms. 1. Termination and propagation kinetics in thiol-ene pohotpolymerizations. Macromolecules 2006, 39, 3673-3680.

23. Northrop, B. H.; Coffey, R. N., Thiol-ene click chemistry: computational and kinetic analysis of the influence of alkene functionality. J. Am. Chem. Soc. 2012, 134, 1380413817.

24. Colak, B.; Da Silva, J. C. S.; Soares, T. A.; Gautrot, J. E., Impact of the molecular environment on thiol-ene coupling for biofunctionalization and conjugation. Bioconj. Chem. 2016, 27 (9), 2111-2123.

25. Fu, A.; Gwon, K.; Kim, M.; Tae, G.; Kornfield, J. A., Visible-light-initiated thiolacrylate photopolymerization of heparin-based hydrogels. Biomacromolecules 2015, 16, 497-506.

26. Lin, T.-Y.; Bragg, J. C.; Lin, C.-C., Designing Visible Light-Cured Thiol-Acrylate Hydrogels for Studying the HIPPO Pathway Activation in Hepatocellular Carcinoma Cells. Macromol. Biosci. 2016, 16, 496-507.

27. Hao, Y.; Lin, C.-C., Degradable thiol-acrylate hydrogels as tunable matrices for three-dimensional hepatic culture. J. Biomed. Mat. Res. A 2014, $102 A$ (11), 3813-3827. 28. Hao, Y.; Shih, H.; Munoz, Z.; Kemp, A.; Lin, C.-C., Visible light cured thiol-vinyl hydrogels with tunable degradation for 3D cell culture. Acta Biomater 2014, 10, 104-114. 29. Young, S. A.; Riahinezhad, H.; Amsden, B. G., In situ-forming, mechanically resilient hydrogels for cell delivery. J. Mat. Chem. B 2019, 7, 5742-5761.

30. Greene, T.; Lin, T.-Y.; Andrisani, O. M.; Lin, C.-C., Comparative study of visible light polymerized gelatin hydrogels for 3D culture of hepatic progenitor cells. J. Appl. Polym. Sci. 2017, 134, 44585.

31. Baudis, S.; Bomze, D.; Markovic, M.; Gruber, P.; Ovsianikov, A.; Liska, R., Modular Material System for the Microfabrication of Biocompatible Hydrogels Based on Thiol-Ene-Modified Poly(vinyl alcohol). J. Polym. Sci., A: Polym. Chem. 2016, 54, $2060-$ 2070.

32. Miquelard-Garnier, G.; Demoures, S.; Creton, C.; Hourdet, D., Synthesis and Rheological Behavior of New Hydrophobically Modified Hydrogels with Tunable Properties. Macromolecules 2006, 39, 8128-8139.

33. Grube, S.; Oppermann, W., Inhomogeneity in hydrogels synthesized by thiol-ene polymerization. Macromolecules 2013, 46, 1948-1955.

34. Li, Y.; Tan, Y.; Xu, K.; Lu, C.; Wang, P., A biodegradable starch hydrogel synthesized via thiol-ene click

chemistry. Polym. Degrad. Stab. 2017, 137, 75-82.

35. Shih, H.; Lin, C.-C., Cross-Linking and Degradation of Step-Growth Hydrogels Formed by Thiol-Ene Photoclick Chemistry. Biomacromolecules 2012, 13, 2003-2012.

36. Megone, W.; Roohpour, N.; Gautrot, J. E., Impact of surface adhesion and sample heterogeneity on the multiscale mechanical charcaterisation of soft biomaterials. Sci. Rep. 2018, 8, 6780 . 
37. Colak, B., Peptide Based Biomaterials via Thiol-ene Chemistry. Queen Mary, University of London 2016.

38. Mathew, A.; Cao, H.; Collin, E.; Wang, W.; Pandit, A., Hyperbranched PEGmethacrylate linear pDMAEMA block copolymer as an efficient non-viral gene delivery vector. International Journal of Pharmaceutics 2012, 434 (1-2), 99-105.

39. Gress, A.; Volkel, A.; Schlaad, H., Thio-click modification of poly 2-(3-butenyl)-2oxazoline. Macromolecules 2007, 40 (22), 7928-7933.

40. Schenk, V.; Ellmaier, L.; Rossegger, E.; Edler, M.; Griesser, T.; Weidinger, G.; Wiesbrock, F., Water-Developable Poly(2-oxazoline)-Based Negative Photoresists. Macromolecular Rapid Communications 2012, 33 (5), 396-400.

41. Dadoo, N.; Landry, S. B.; Bomar, J. D.; Gramlich, W. M., Synthesis and Spatiotemporal Modification of Biocompatible and Stimuli-Responsive Carboxymethyl Cellulose Hydrogels Using Thiol-Norbornene Chemistry. Macromol. Biosci. 2017, 17, 1700107.

42. Stephens, P.; Grenard, P.; Aeschilmann, P.; Langley, M.; Blain, E.; Errington, R.; Kipling, D.; Thomas, D.; Aeschlimann, D., Crosslinking and G-protein functions of transglutaminase 2 contribute differentially to fibroblast wound healing responses. Journal of Cell Science 2004, 117 (15), 3389-3403.

43. Hoyle, C. E.; Bowman, C. N., Thiol-ene click chemistry. Angew. Chem., Int. Ed. 2010, 49, 1540-1573.

44. Serjeant, E. P.; Dempsey, B., Ionization constants of organic acids in aqueous solutions. Pergamon Press: Oxford, 1979.

45. Murmiliuk, A.; Košovan, P.; Janata, M.; Procházka, K.; Uhlík, F.; Štěpánek, M., Local pH and Effective pK of a Polyelectrolyte Chain: Two Names for

One Quantity. ACS Macro Lett. 2018, 7, 1243-1247.

46. Nova, L.; Uhlı, F.; Kosovan, P., Local pH and effective pKA of weak polyelectrolytes - insights from computer simulations. Phys. Chem. Chem. Phys. 2017, 19, 14376-14387.

47. Lin, C.-C.; Raza, A.; Shih, H., PEG hydrogels formed by thiol-ene photo-click chemistry and their effect on the formation and recovery of insulin-secreting cell spheroids. Biomaterials 2011, 32, 9685-9695.

48. Fairbanks, B. D.; Schwartz, M. P.; Halevi, A. E.; Nuttelman, C. R.; Bowman, C. N.; Anseth, K. S., A versatile synthetic extracellular matrix mimic via thiol-norbornene photopolymerization. Adv. Mater. 2009, 21, 5005-5010.

49. Koo, S. P. S.; Stamenovic, M. M.; Prasath, R. A.; Inglis, A. J.; Du Prez, F. E.; Barner-Kowollik, C.; Van Camp, W.; Junkers, T., Limitations of radical thiol-ene reactions for polymer-polymer conjugation. J. Polym. Sci., A: Polym. Chem. 2010, 48 (8), 16991713. 